\title{
Economic analysis of local food procurement in Southwest Florida's farm-to-school programs
}

\author{
Jonathan Adam Watson, ${ }^{\mathrm{a} *}$ Danielle Treadwell, ${ }^{\mathrm{b}}$ and Ray Bucklin ${ }^{\mathrm{c}}$ \\ University of Florida
}

Submitted February 27, 2018 / Revised May 29 and July 12, 2018 / Accepted July 13, 2018 /

Published online November 6, 2018

Citation: Watson, J. A., Treadwell, D., \& Bucklin, R. (2018). Economic analysis of local food procurement in Southwest Florida's farm-to-school programs. Journal of Agriculture, Food Systems, and Community Development, 8(3), 61-84. https://doi.org/10.5304/jafscd.2018.083.011

Copyright (C) 2018 by the Authors. Published by the Lyson Center for Civic Agriculture and Food Systems. Open access under CC BY license.

\begin{abstract}
Farm-to-school (F2S) programs aim to educate people about food and farming, to increase the availability of fresh, nutritious foods, and to improve health outcomes among children. Nationally, all states have school districts that selfidentify as farm-to-school program participants. National and regional food procurement systems account for the majority of food purchased by National School Lunch Program participants, but school foodservice authorities (SFA) who purchase food from farmers often do so in the context of strengthening their farm-to-school program (U.S.
\end{abstract}

a * Corresponding author: Jonathan Adam Watson, Department of Agricultural and Biological Engineering; 1741 Museum Road; University of Florida; Gainesville, Florida 32611 USA; +1-352-294-6740; jaw7385@ufl.edu

b Danielle Treadwell, Horticultural Sciences Department; 1253 Fifield Hall; University of Florida; Gainesville, Florida 32611 USA; +1-352-273-4774; ddtreadw@ufl.edu

c Ray Bucklin, Department of Agricultural and Biological Engineering; 1741 Museum Road; University of Florida; Gainesville, Florida 32611 USA; +1-352-294-6718; bucklin@ufl.edu
Department of Agriculture [USDA], n.d.-b). A greater number of local supply chain participants benefit when food is sourced in state (locally) rather than out-of-state because more money ends up in the pockets of local producers and distributors. Local fruit and vegetable producers and SFAs interested in developing business partnerships for local procurement would benefit from recommendations on menu-appropriate fresh market products, volume, and purchase prices. However, detailed data sets from SFAs are uncommon, limiting opportunities to advance procurement

\section{Funding Disclosure}

The authors of this publication have research support from the Florida Department of Agriculture and Consumer Services (FDACS) and the Sustainable Agriculture Research and Education (SARE) program. The terms of this arrangement have been reviewed and approved by the University of Florida in accordance with its policy on objectivity in research.

We extend our sincere appreciation to the Southern Region of the Sustainable Agriculture Research and Education (SARE Graduate Student Research Award Project \# GS15-141) and to the Florida Department of Agriculture and Consumer Services for their financial support. Their assistance was critical in making this research project possible. 
efforts. The objective for this project was to begin developing local procurement recommendations for other Florida school districts based on the purchasing history and experiences of the Sarasota County School District (SCSD).

In 2014, Sarasota County, Florida, received a USDA F2S implementation grant, affording it the opportunity to develop its local procurement efforts. One deliverable from that project was a robust data set of school food purchases over a two-year period. With permission SCSD, we analyzed seasonal purchase variations and market prices of local and out-of-state fresh fruits, vegetables, and egg purchases for 38 public schools in the SCSD. In this paper, we present an approach to estimate the potential of local procurement viability in the context of an emerging districtwide F2S program and recommend system changes based on the success of procurement efforts in SCSD and surrounding school districts in Southwest Florida.

\section{Keywords}

Community Development, Farmers, Farm to School, Florida, Food Systems, Local Food Procurement, Seasonal Availability, Specialty Crops, Title I Schools

\section{Introduction and Literature Review}

Farm to school (F2S) is a national movement with the goals of educating persons, particularly children, on where and how their food is grown, improving nutrition, reducing childhood obesity, increasing physical activity, enhancing community development, and supporting local farmers (Izumi, Wright, \& Hamm, 2010; National Farm to School

Network, n.d.-b; Winston, 2011). As is often the case across the nation, school districts in the state of Florida procure a large portion of their food from government programs, including the Department of Defense Fresh Fruit and Vegetable Program or USDA Foods in Schools, at low cost. These monetary incentives have been federal policy in the U.S. since the creation of the National School Lunch Act of 1946 (2010). This act provides federal funds to purchase and distribute food among participating schools. SFAs receive a specified reimbursement from the federal government for every meal served free or at a reduced price to children whose households' limited incomes qualify them for support. At the time of this study (2014), the threshold for reduced price lunch was $185 \%$ of the poverty line (a maximum of US $\$ 44,123$ for a family of four), while the threshold for free lunch was $130 \%$ of the poverty line (a maximum of US $\$ 31,005$ for a family of four).

Although Department of Defense and USDA Foods in Schools provide the necessary minimum requirements for the student's nutrition, much of the food is dried, frozen, or canned in addition to being procured from other states. Fruits and vegetables represent significant expenditures by the school district and are often not eaten by children, contributing to plate waste, or the edible portion of food served that is uneaten and discarded. In a study by Cohen, Richardson, Austin, Economos, and Rimm (2013), 73.3\% of vegetables and $46.8 \%$ of fruit per meal component on average were wasted, accounting for annual waste costs of US $\$ 100,393$ and US $\$ 33,532$, respectively, for Boston Public Schools. Transportation of these products over long distances also has an environmental impact. While in some cases it may be more environmentally desirable to transport food rather than degrading local resources (Morgan \& Sonnino, 2008) or spending greater energy to grow it locally, in other cases there is opportunity. Florida has an ideal climate for year-round production of a wide variety of products as well as the support industries for processing these products (e.g., citrus).

Historically, these policies have benefited schools by assisting them with access to affordable food and have acted as a price support for producers during times when market conditions were unfavorable or when food prices were low. Additionally, farm policy in the United States has focused increasingly on driving down the price of commodity products like corn and soybean, with very little support for the production of fruits and vegetables and other specialty crops (Schoonover \& Muller, 2006). Today, many schools participating in National School Lunch Program (NSLP) buy food in prearranged volumes, and in recent years little of the product represents actual surplus. In 2015 , less than $1 \%$ of total federal cost for school food purchases represented bonus or surplus in the 
market (USDA Food \& Nutrition Service, 2017). While these farm policies may have benefited many producers financially, in many other ways they have been unsuccessful. Supports for commodities such as corn and soybeans, often used in producing animal feeds and other processed foods, have driven down the cost of meat products as well as other fattening, sweet, or salty foods such as prepackaged snacks, ready-to-eat meals, fast food, and soft drinks (Fields, 2004). The cost of fresh fruits and vegetables remains significantly high relative to an SFA's food budget; however, in some cases, fruits and vegetables purchased locally may eliminate some handling and transportation costs associated with land-distance suppliers, helping to cut costs for schools (Izumi, Rostant, Moss, \& Hamm, 2006).

The Dietary Guidelines for Americans clearly state that throughout their lifespan, optimal nutrition plays an important role in a child's growth development (USDA \& U.S. Department of Health and Human Services, 2010). Studies suggest that F2S programs have the potential to be an effective strategy that communities and schools can implement to improve children's health (Berlin, Norris, Kolodinsky, \& Nelson, 2013; Bontrager Yoder, 2014). Indeed, schools are a natural setting for influencing a child's activity and play an important role in influencing the eating patterns and behavior of children (Dehghan, Akhtar-Danesh, \& Merchant, 2005). It is estimated that school-aged children eat between $19 \%$ and $50 \%$ percent of their total daily calories at school (Gleason \& Suitor, 2001). Unfortunately, food offerings at schools are often high in sodium, sugar, and fats and low in vitamins and nutrients (Centers for Disease Control and Prevention, 2009). However, it should be noted that there have been some positive changes. Under the Obama administration, the 2015-2020 Dietary Guidelines were revised to (1) follow a healthy eating pattern across the lifespan; (2) focus on variety, nutrient density, and quantity; (3) limit calories from added sugars and saturated fats, and reduce sodium intake; (4) shift to healthier food and beverage choices; and (5) support healthy eating patterns for all (U.S. Department of Health and Human Services \& USDA, 2015). As such, "school staff members supervising cafeteria time should model healthy habits and use appropriate supervisory techniques for managing the school cafeteria" (Centers for Disease Control and Prevention, 2011, p. 52).

Low-income or impoverished families are at a major disadvantage when it comes to purchasing healthy food such as fresh fruits and vegetables, resulting in infrequent consumption of these foods by children from these families. Indeed, poverty and food insecurity are associated with lower food expenditures, low fruit and vegetable consumption, and lower-quality diets (Drewnowski \& Specter, 2004). In addition, children from low-income families are often less knowledgeable about nutrition. Hall, Chai, and Albrecht (2016) found differences in nutrition knowledge and behavior outcomes between students surveyed at Title I and non-Title I schools. ${ }^{1}$ Nutrition education at home, or the lack thereof, is not the entire problem.

Although parental involvement in conjunction with communitywide programs and policies are essential to developing healthful eating habits in children (Lindsay, Sussner, Kim, \& Gortmaker, 2006), cost, difficulty getting children to eat healthy foods, and easy access to fast foods remain significant barriers (Slusser et al., 2011).

Finkelstein, Hill, and Whitaker (2008) concluded that as students move to higher grade levels, à la carte and competitive foods sold through vending machines become more readily available and their eating habits become less healthy. Consumption of these unhealthy foods by adolescents is associated with decreased consumption of school lunch servings and decreased nutrient intake as well

\footnotetext{
1 Title I schools are local educational agencies (LEAs) and schools with high numbers or high percentages (at least $40 \%$ of enrollment) of children from low-income families. When a certain percent of the school's student population meets the requirement for a free or reduced lunch, the school is designated as Title I and is eligible to receive special funding. Schools with $75 \%$ of students whose families are classified as impoverished are automatically allocated Title I funds, while schools with 35\% (or higher than the country's average) of students who qualify for reduced price or free of charge lunches are also eligible. Ultimately, it is the discretion of the school district as to the number of schools it serves.
} 
as increased contribution to plate waste (Templeton, Marlette, \& Panemangalore, 2005). The availability of competitive foods is associated with lower consumption of fruits and vegetables and higher intakes of total fat and saturated fat (Kubik, Lytle, Hannan, Perry, \& Story, 2003). Because students spend such a large portion of their day in schools, schools are in a unique position to influence the dietary habits of schoolchildren (Story, Kaphingst, \& French, 2006). The need for healthy school cafeteria food is great, but prohibitive costs, budgetary and personnel constraints, and limited alternatives for procurement force many school districts to make difficult decisions.

Until recently, very few researchers have looked at schools procuring fresh foods from local sources through traditional distribution channels. In 1996 and 1997, the first F2S pilot programs were established in California (Santa MonicaMalibu USD and The Edible Schoolyard, Berkeley) and in Florida as the New North Florida Marketing Cooperative (National Farm to School Network, n.d.-a). The Santa Monica program's fruit and vegetable salad bar offered children from lowincome families a replacement to cafeteria offerings; due to its popularity, the salad bar became standard at every school in the district (Vallianatos, Gottlieb, \& Haase, 2004). The program in North Florida eventually reached parts of Georgia and Alabama; however, the results of those efforts were mixed due to issues regarding distribution, logistics, and quality control. Both programs were important steps for the growing F2S movement and the creation of a national F2S network.

Some tools exist to assist producers and schools in the procurement process. Holcomb and Vo (n.d.) developed an F2S distribution cost template that incorporates vehicle operating costs, fuel economy, maintenance, repairs, and insurance, as well as depreciation and labor. Watson, Treadwell, Prizzia, and Brew (2014) developed a farm-toschool procurement calculator to assist specialty crop producers and school foodservice staff in converting bulk units (bushels, crates, etc.) into 1/4-, $1 / 2-$, and 1 -cup serving sizes. These tools can aid in procurement transaction decision-making by easily converting units and estimating costs.
While the F2S movement is popular, and the concepts and ideas are sensible, the successful implementation of many activities has proven to be challenging. The economies of scale regarding school food, as well as local, state, and national food and farm policies have made local procurement quite difficult (Joshi, Azuma, \& Feenstra, 2008). Despite these challenges, the procurement of local and regional foods by schools, and the education of children and communities about local products, are important factors in creating demand for such products, and are critical to the goals of F2S activities (Joshi, Henderson, Ratcliffe, \& Feenstra, 2014). Schools operate on limited budgets, and so maintaining low costs is extremely important to ensure cafeterias continue to operate and serve children. Some studies have suggested that, in addition to strategies to reduce the cost of local food, the creation of programming that builds relationships between school foodservice buyers has the potential to result in increased local procurement (Roche, Conner, \& Kolodinsky, 2015). The National Farm to School Network, for example, has a number of tools, including its State Farm to School Networks Toolkit that includes information for establishing a robust network structure (National Farm to School Network, 2018).

During the 2014-2015 school year, the SCSD made positive headway in its effort to create a successful F2S procurement strategy and expand local food offerings in its cafeterias. Indeed, expenditures for local food purchases by the SCSD more than doubled from the previous school year, and small farm producers heralded the progress as a positive step for those interested in direct sales to institutions like schools (Benson, Russell, \& Kane, 2015). Further evidence includes testimony from personnel in the Food and Nutrition Services of the Sarasota County School Board, stating that much of this success is due to the factors including (1) passionate people (i.e., champions) who believe in the vision of F2S and who advocate its benefits, (2) commitment of dedicated personnel responsible for procurement coordination efforts with producers and school foodservice, and (3) an investment in financial resources to support personnel, such as a dedicated coordinator to 
synchronize F2S efforts between the school district and local producers. While it is important to view these strides positively, it is equally important to recognize that much more work is necessary.

Like many urbanized areas in Florida, Sarasota County has experienced significant growth due to the demands of increased population. Large tracts of land that were once used for agricultural production are now zoned for commercial, industrial, or residential use. From 2007 to 2012, the number of farms in Sarasota County decreased $7.2 \%$, from 305 to 283 total farms, while average farm size has increased $41.5 \%$ from 200 to 283 acres (81 to 115 hectares) (USDA, n.d.-a). This trend of consolidation of farmland is like other areas in Florida and throughout the U.S. As patterns of land use in the county shift, so too do people's access to fresh, locally sourced food products, as well as their interactions with local producers. While patterns of land use (agricultural and urban) and the associated boundaries of food systems can shift rapidly, political boundaries change less frequently. This is important because researchers and policy-makers often have different definitions of what is local, and most are guided by political or geographic boundaries. This reality, coupled with nonstandardized food ordering and procurement systems, leads to a complex network of relationships with SFAs, distributors, and producers with no onesize-fits-all analytical approach (Watson, 2016).

In many cases, development and urbanization, as well as race and class issues, have created areas where access to fresh food products is difficult. These areas, known as food deserts, are often located in proximity to schools, as seen in Appendix A. Many households in these urban areas also have a greater number of children whose families are eligible for Supplemental Nutrition Assistance Program (SNAP), commonly known as food stamps. This issue is greater for children from minority groups, as nonwhite families with children compose $52.3 \%$ of households participating in SNAP nationwide (USDA Food \& Nutrition Service, 2016). As with Sarasota County, many schools in Florida are in urban areas where a larger number of SNAP-eligible children reside (Appendix B).

In 2014, the Food and Nutrition Services of the Sarasota County School Board was awarded a US $\$ 100,000$ USDA Farm to School implementation grant. Those funds partially supported the hiring of a dedicated farm-to-school coordinator tasked with enhancing communication between SFA, distributors, and local producers. Contact between SCSD and researchers at the University of Florida's Farm to School Program was made and resulted in a collaboration. That collaboration provided us as researchers at the University of Florida with a rare opportunity to analyze local food purchases of an entire school district. Our analysis offered insight into the types, volume, and price of commodities purchased by the SCSD during the 2014-2015 school year, compared to the previous school year. In addition, researchers analyzed and compared differences in the percentages of local food purchased by Title I and non-Title I schools in the district. It is believed these analyses will help SFA create more effective procurement strategies and assist local food producers in making better marketing decisions.

The need for more nutritious, locally produced foods, particularly by children from low- income families at Title I schools, presents a unique marketing opportunity for producers. Watson, Treadwell, and Bucklin (2018) present survey data and interviews from producers of different farm sizes in the Southwest Florida area regarding production, distribution, and transportation capabilities; markets served; and interest in organizing a cooperative to serve institutions like schools. Producers agreed that selling to schools is an important marketing opportunity, and small producers expressed strong interest in forming a cooperative to sell fresh fruits and vegetables to schools. However, most expressed concern and frustration about compliance from distributors. One producer who had previously won a bid to sell to a school district indicated that their product never arrived at the schools, and that the lack of traceability and accountability in the system discouraged them further working with the school district. Certainly, incidents like these can stifle the development and success of F2S programs as farmers feel sidelined. While issues with distribution are a major obstacle in and of themselves, identifying the quantity, type, and price paid for local products is a necessary 
initial step in establishing relationships and coordinating transactions among producers and school districts.

The goal of this work is to present a method for estimating the potential for local procurement by describing, analyzing, and reporting local food procurement in the context of an emerging F2S program in Sarasota County, Florida. Previous research describes the benefits of F2S, but often lacks a detailed account of specific procurement activities that aid decision-making. While there are studies that use a qualitative case study approach (Izumi, Alaimo, \& Hamm, 2010), or a survey (Colasanti, Matts, \& Hamm, 2012), most do not provide a detailed analysis of all the procurement activity for specific products at the district level over time. Therefore, the research objectives of this paper are to:

1. Summarize total fresh and locally produced food products by the Sarasota County School District during the 20142015 academic year;

2. Describe trends and seasonal patterns of total fresh food and local food purchases by the Sarasota County School District during the 2014-2015 academic year; and

3. Identify opportunities to expand local procurement of fresh fruits and vegetables in Southwest Florida.

\section{Methods}

We as researchers at the University of Florida analyzed purchase report data acquired from distributor invoice lists of food purchased by the SCSD after USDA implementation grant funds were used to hire a dedicated F2S coordinator. Data for school food purchases from the SCSD during the 2014-2015 academic school year ranged from July 7, 2014, to May 20, 2015. Products included fresh fruits, vegetables, and eggs, purchased by 38 public elementary, middle, and high schools within the county. Each weekly purchase report contained an invoice number, the name of the school where the product was delivered, an invoice date, and a school identification number. Additionally, the same line provided a description of the product purchased (commodity name and pack size), the quantity of the product ordered (unit), the price per unit, the line-ordered amount (price per unit times the number of units ordered), the quantity delivered, the price per unit delivered, and the total dollar amount of the product delivered.

The data were analyzed using Microsoft Office Excel 2016. The software made it possible to aggregate, sort, and compile meaningful statistics for an entire academic calendar year. Columns containing total dollar amount spent were searched and aggregated using a SUMIF function statement in Excel. The function searches the column and sums or aggregates all values from the array that meet only the criteria or argument specified. In this case, that criterion is the production description (e.g., "oranges"). The SUMIF function assists with extrapolating the total market value and weight of each commodity from the purchase report data. With this method, it is relatively easy and efficient to sort through hundreds of line items and aggregate only those values that match the argument. This allows for easy calculation of market value per unit as well as the price per serving with USDA conversion factors considered.

Just analyzing the total amount of fresh food purchases by each of the schools within the district reveals very little useful information. This is because the amount spent by each school on average will be proportional to the number of students who attend. In other words, the larger the student body, the greater the amount spent on fresh fruits and vegetables by that school. Regarding F2S, it is more appropriate to analyze the quantity of locally sourced product. Again, because this amount depends on the number of students enrolled at each school, it is more appropriate to calculate the amount of Florida-sourced products as a percent of the school's total food fresh food purchases. This allows us to determine which schools, in relation to others in their district, are more proactive at (or better equipped for) sourcing locally produced fresh food products.

Segmenting schools based on socioeconomic factors, student enrollment, and location to make meaningful comparisons is problematic when the sample size (i.e., the number of schools in the district) is small and certain data sets are not 
available. We analyzed data on local food purchases from with Title I schools and compared those figures to non-Title I schools. We employed a Wilcoxon Rank-Sum Test, as it is quite suitable for handling data when small sample sizes are present. In the Wilcoxon Rank-Sum Test, the goal is to calculate, with a specific certainty, whether there is a statistical difference in the median between the samples in study. The null hypothesis of the test assumes there are no statistical differences in the median difference between Title I and non-Title I schools, such that:

$$
\begin{aligned}
& H_{O}: \text { Median }(\text { difference })=0 \\
& H_{A}: \text { Median }(\text { difference }) \neq 0
\end{aligned}
$$

The alternative hypothesis in this study assumes with at least $99 \%(\alpha=0.01)$ certainty that there is a statistically significant difference between the median values of the two groups. The two samples compared test the hypotheses of differences between Title I schools and non-Title I schools in the SCSD regarding the amount spent on Florida-grown products by each school in the district, as a percent of their total fresh fruit and vegetables purchases.

The Wilcoxon Rank-Sum Test is conducted by organizing all data points for Florida-grown products as a percent of total purchases for each sample containing both Title I and non-Title I schools into a single column. Each sample is then counted where Title I schools are classified as sample $1\left(n_{1}\right)$ and non-Title I schools are classified as sample $2\left(n_{2}\right)$. An adjacent column uses binary values where " $1=$ Title I" and " 0 "=non-Title I" to distinguish between the two types of schools. The data points are sorted from smallest to largest and ranked in ascending order. In the Wilcoxon RankSum Test, samples that have the same value are assigned an average of that rank. The samples are then re-sorted to signify Title I or non-Title I to calculate $\mathrm{N} 1$ and $\mathrm{N} 2$ (not $n_{1}$ and $n_{2}$ ), where $\mathrm{N} 1$ is the sum of the ranks of all samples in the first group and N2 is the sum of the ranks of all samples in the second group. The next step in the test requires calculating the value for $R$, which in the Wilcoxon Sum-Rank Test is equal to either N1 or N2, whichever has the smaller sample size.

Once the value of $R$ is established, it is necessary to calculate the $\mathrm{Z}$ score and $\mathrm{Z}$ critical values to determine if sample groups exhibit differences in their median values. It is necessary to first obtain $\mu_{R}$ (Equation 1) and $\sigma_{R}$ (Equation 2), where $\mu_{R}$ is the estimate of the mean for the population, and $\sigma_{R}$ is an estimate of the standard deviation. Then the $\mathrm{Z}$ score (Equation 3) can be determined so that it can be compared to the critical value. A summary of equations and variables used in the analysis can be found in Appendix C. The counts of the samples for $n_{1}$ and $n_{2}$ are used in the calculation of $\mu_{R}$ and $\sigma_{R}$.

\section{Results and Discussion}

The total market value, and therefore the total cost to the SCSD for all fresh fruit and vegetable products purchased regardless of origin, was US $\$ 855,102$. Total fresh fruit and vegetable purchases, excluding eggs, totaled US\$849,817. A detailed list of the market value, weight, cost per pound, and cost per serving for all food products purchased by Sarasota County is in Appendix D. The top 15 products accounts for US $\$ 653,307$, or $77.0 \%$ of the total expenses thus far for the county (Figure 1). Sliced apples ranked first in terms of market value, accounting for US\$142,982 of purchases or approximately $17.0 \%$ of total cost. Broccoli florets, which ranked second, and whole carrots, which ranked third, were also significant sources of expenses, with US\$73,796 (9.0\%) and US\$51,798 (6.0\%) spent, respectively.

Of all products purchased during the 2014 2015 school year, fresh herbs were by far the most expensive products per pound. Fresh sage, oregano, dill, thyme, basil, rosemary, and mint were the top seven most expensive products per pound, in that order. Excluding herbs, snack pack blueberries were the most expensive product, averaging US $\$ 12.72 / \mathrm{lb}$. However, the school district only purchased $163 \mathrm{lb}$. $(74 \mathrm{~kg}$ ) of snack pack blueberries, which represented a rather insignificant quantity. Sliced mango was also quite expensive at US $\$ 9.24 / \mathrm{lb}$. with $81 \mathrm{lb}$. $(37 \mathrm{~kg})$ purchased. Similarly, snack pack pumelo averaged US $\$ 5.15 / \mathrm{lb}$. with $346 \mathrm{lb} .(157 \mathrm{~kg})$ purchased. The expense of these products is likely attributed to the valueadded processing, packaging, and convenience. Spring-mix lettuce averaged US $\$ 4.80 / \mathrm{lb}$., ranking 
Figure 1. Top 15 Products as Percentage of Total Annual Cost

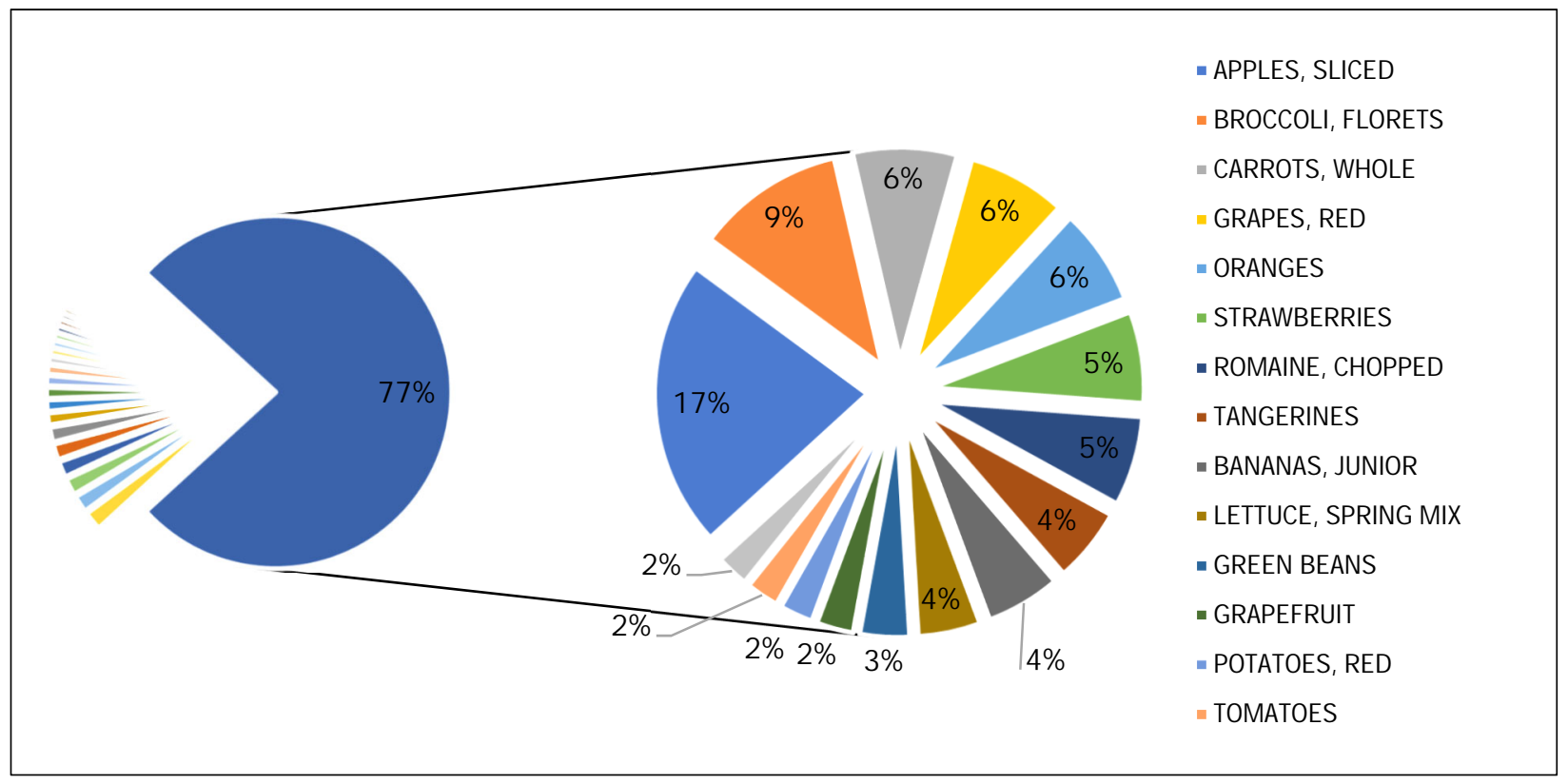

thirteenth of all products purchased. Additionally, pineapple chunk snack packs at US $\$ 4.56 / \mathrm{lb}$. and honeydew snack packs at US $\$ 4.40 /$ lb. ranked fourteenth and fifteenth, respectively; however, they too are purchased in low volume. The most expensive products per serving were mango slices, snack pack blueberries, and pineapple chunks at US $\$ 1.22$ /serving, US $\$ 1.19 /$ serving, and US $\$ 0.71$ / serving respectively. Again, value-added products are significantly more expensive than minimally processed fruits and vegetables.

Sarasota County purchased 36 different Florida-grown fruit and vegetable products with a market value of US $\$ 269,379$. Florida-grown products represented $31.7 \%$ of the total market value of all food spent by the SCSD for the academic year. Of all Florida-grown fruits and vegetable products purchased, strawberries had the largest market value of US $\$ 44,896$ (Table 1). Local strawberries account for $16.4 \%$ of total local purchases and $98.8 \%$ of all strawberries purchased during the entire school year. Locally sourced strawberries cost US $\$ 2.27 / \mathrm{lb}$. or US $\$ 0.29$ per $1 / 4$ cup (32 g) serving. Florida-grown oranges ranked second with US $\$ 33,978$ spent, accounting for $12.4 \%$ of total local purchases, with $70.6 \%$ of all oranges purchased being sourced from with the state. Red potatoes, grapefruit, grape tomatoes, tomatoes (slicers), cucumbers, watermelon, cherry tomatoes, fingerling potatoes, broccoli florets, and zucchini squash accounted for significant sources of local food purchases during the 2014-2015 academic year. These top 15 products purchased represent $92.2 \%$ of all Florida-grown produce, with a market value of US\$248,416. A complete list of all local products including their total market value, total weight, cost per pound, and cost per serving is in Appendix E.

The top three local food products by total, local, and potential purchase for fruit and vegetable subgroups are in Table 2 . For fruit, locally produced strawberries accounted for the largest purchase with US $\$ 44,896$, but oranges have the greatest potential for local sourcing with US\$14,125. Within the dark green subgroup, locally produced spring-mix lettuce was the largest purchase with US $\$ 30,851$, whereas broccoli florets have the largest potential within the category at US\$68,319. Tomatoes (slicers) had the largest potential purchase of all red/orange vegetables with US $\$ 5,271$, even though local grape tomatoes accounted for the largest purchase by product within the category with US $\$ 11,176$. For starchy vegetables, red potatoes were the top local product purchased within 
Journal of Agriculture, Food Systems, and Community Development

ISSN: 2152-0801 online

https://www.foodsystemsjournal.org

Table 1. Top 15 Local Food Products

\begin{tabular}{lccccc}
\hline Local Product & $\begin{array}{c}\text { Total Purchases } \\
\text { (US\$) }\end{array}$ & $\begin{array}{c}\text { \% of Total Local } \\
\text { Purchases }\end{array}$ & $\begin{array}{c}\text { \% of Total Product } \\
\text { Purchases }\end{array}$ & $\begin{array}{c}\text { Cost per Pound } \\
\text { (US } \$ \text { ) }\end{array}$ & $\begin{array}{c}\text { Cost per Serving } \\
\text { (1/4 cup or 32 g) }\end{array}$ \\
\hline Strawberries & $\$ 44,896$ & $16.4 \%$ & $98.8 \%$ & $\$ 2.27$ & $\$ 0.29$ \\
\hline Oranges & $\$ 33,978$ & $12.4 \%$ & $70.6 \%$ & $\$ 0.57$ & $\$ 0.16$ \\
\hline Tangerines & $\$ 33,903$ & $12.4 \%$ & $91.3 \%$ & $\$ 0.64$ & $\$ 0.08$ \\
\hline Lettuce, Spring Mix & $\$ 30,851$ & $11.2 \%$ & $99.7 \%$ & $\$ 4.83$ & $\$ 0.22$ \\
\hline Green Beans & $\$ 19,968$ & $7.3 \%$ & $100.0 \%$ & $\$ 1.80$ & $\$ 0.08$ \\
\hline Potatoes, Red & $\$ 15,826$ & $5.8 \%$ & $100.0 \%$ & $\$ 0.56$ & $\$ 0.06$ \\
\hline Grapefruit & $\$ 11,855$ & $4.3 \%$ & $64.7 \%$ & $\$ 0.59$ & $\$ 0.09$ \\
\hline Tomatoes, Grape & $\$ 11,176$ & $4.1 \%$ & $75.3 \%$ & $\$ 2.16$ & $\$ 0.18$ \\
\hline Tomatoes & $\$ 11,119$ & $4.1 \%$ & $67.8 \%$ & $\$ 0.88$ & $\$ 0.12$ \\
\hline Cucumbers & $\$ 7,076$ & $2.6 \%$ & $52.8 \%$ & $\$ 0.73$ & $\$ 0.07$ \\
\hline Watermelon & $\$ 5,848$ & $2.1 \%$ & $47.4 \%$ & $\$ 0.43$ & $\$ 0.003$ \\
\hline Tomatoes, Cherry & $\$ 5,745$ & $2.1 \%$ & $64.9 \%$ & $\$ 2.23$ & $\$ 0.18$ \\
\hline Potatoes, Fingerlings & $\$ 5,499$ & $2.0 \%$ & $100.0 \%$ & $\$ 1.17$ & $\$ 0.12$ \\
\hline Broccoli, Florets & $\$ 5,477$ & $2.0 \%$ & $7.4 \%$ & $\$ 3.50$ & $\$ 0.12$ \\
\hline Zucchini, Squash & $\$ 5,201$ & $1.9 \%$ & $61.9 \%$ & $\$ 1.09$ & $\$ 0.09$ \\
\hline
\end{tabular}

Table 2. Fresh Food Purchases by Market Value for Fruit and Vegetable Subgroups for 2014-2015 Academic School Year

\begin{tabular}{llrrr}
\hline Subgroup & Product & $\begin{array}{c}\text { Total Purchase } \\
\text { (US\$) }\end{array}$ & $\begin{array}{r}\text { Local Purchase } \\
\text { (US\$) }\end{array}$ & $\begin{array}{r}\text { Potential Purchase } \\
\text { (US\$) }\end{array}$ \\
\hline Fruit & Strawberries & $\$ 45,454$ & $\$ 44,896$ & $\$ 557$ \\
\hline Oranges & $\$ 48,103$ & $\$ 33,978$ & $\$ 14,125$ \\
\hline Dark green & Tangerines & $\$ 37,148$ & $\$ 33,903$ & $\$ 3,245$ \\
\hline & Lettuce, Spring Mix & $\$ 30,929$ & $\$ 30,851$ & $\$ 78$ \\
\hline & Broccoli, Florets & $\$ 73,796$ & $\$ 5,477$ & $\$ 68,319$ \\
\hline Red/Orange & Romaine, Whole & $\$ 4,479$ & $\$ 1,302$ & $\$ 3,177$ \\
\hline & Tomatoes, Grape & $\$ 14,843$ & $\$ 11,176$ & $\$ 3,667$ \\
\hline Starchy & Tomatoes & $\$ 16,389$ & $\$ 11,119$ & $\$ 5,271$ \\
\hline & Tomatoes, Cherry & $\$ 8,856$ & $\$ 5,745$ & $\$ 3,111$ \\
\hline Potatoes, Red & $\$ 16,742$ & $\$ 15,826$ & $\$ 916$ \\
\hline Other & Potatoes, Fingerling & $\$ 5,499$ & $\$ 5,499$ & $\$-$ \\
\hline & Corn, Cob & $\$ 13,263$ & $\$-$ & $\$ 13,263$ \\
\hline Green Beans & $\$ 24,591$ & $\$ 19,968$ & $\$ 4,623$ \\
\hline Unclassified & Cucumbers, Whole & $\$ 13,393$ & $\$ 7,076$ & $\$ 6,317$ \\
\hline & Squash, Large & $\$ 8,400$ & $\$ 5,201$ & $\$ 3,199$ \\
\hline & Dill, Fresh & $\$ 5,285$ & $\$ 4,882$ & $\$ 403$ \\
\hline & Oregano, Fresh & $\$ 359$ & $\$ 355$ & $\$ 4$ \\
\hline
\end{tabular}

For other vegetables produced locally, green beans were the top product with US $\$ 19,968$, while the potential purchase was greatest for whole cucumbers with US\$6,317.

F2S procurement covers a wide variety of locally sourced food products, such as meats, dairy products, and baked goods; however, most procurement activity focuses on purchasing fruits and vegetables. In contrast to other areas in the United States, Florida's climate is well suited

the category with US $\$ 15,826$; however, the starchy product with the greatest potential purchase was sweet corn on the cob, as none of the corn purchased in the 2014-2015 academic year was local. to producing a wide variety of fruits and vegetables, particularly during the late fall, winter, and early spring months when schools are in session. Figure 2 shows local and non-local fresh food 
Figure 2. Sarasota County (Florida [FL]) School District M onthly Purchases of Fresh Local and Non-Local Food, 2014-2015 Academic Year

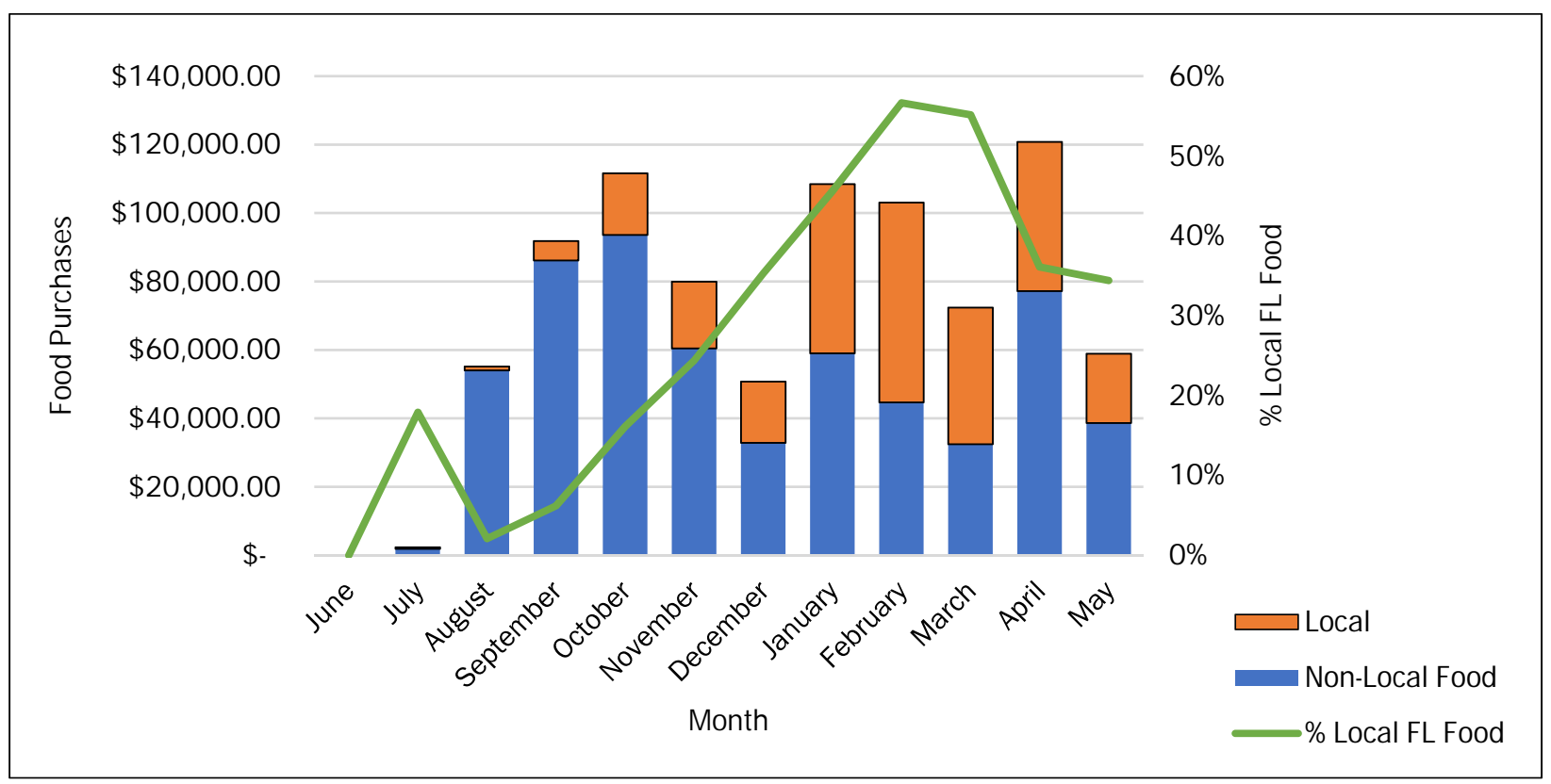

purchases by the SCSD for the 2014-2015 academic year. Florida's commercial production season is aligned with serving markets that are incapable of producing food, most notably in winter months. In general, small amounts of local fresh food purchases (e.g., watermelon) are available during late summer months from July going well into November and December. Holiday breaks ensure that food expenditures in general are limited, particularly during the winter break in late December. However, as Florida's commercial season progresses, crops such as winter greens (kale, collards, mustards), oranges, strawberries, cabbage, and potatoes become available to schools for purchase.

The USDA's MyPlate nutrition guide suggests a focus on making healthy food and beverage choices from all five food groups including fruits, vegetables, grains, protein foods, and dairy to get the essential nutrients (USDA \& U.S. Department of Health and Human Services, 2010). MyPlate also suggests that $50 \%$ of a meal consists of fresh whole fruits and a variety of vegetables. Vegetables are further classified into five subgroups: (1) dark green, (2) red/orange, (3) starchy, (4) peas and beans, and (5) other. Examples of dark green vegetables include kale, collards, and spinach; red/orange vegetables include carrots, pumpkin, and red peppers; starchy vegetables include potatoes and sweet corn; peas and beans include blacked-eye peas and lima beans; and other vegetables include summer yellow and zucchini squash varieties, green peppers, and celery.

The fresh food category with the highest expenditure by far is fruit, with US $\$ 439,312$ in total purchases, of which US\$130,479 (29.7\%) was local food (Figure 3). Dark green vegetables total US $\$ 164,308$ with US $\$ 38,532$ (23.5\%) sourced from Florida. Red/orange vegetables accounted for US $\$ 109,674$, with $\$ 28,401$ (25.9\%) sourced from the state. Vegetables categorized as other or starchy totaled US $\$ 87,005$ and US $\$ 48,015$, respectively, while the locally produced share of each was US $\$ 49,407(56.8 \%)$ for other and US $\$ 21,325$ (44.4\%) for starchy. Sarasota County did not purchase any peas or beans, but there were additional vegetables purchased-primarily herbs - that did not correspond to any of the recognized MyPlate vegetables subgroups. These were categorized as "unclassified" and totaled US\$6,514, of which US $\$ 6,117$ (93.9\%) were locally produced.

Fruits and vegetables were categorized by MyPlate subgroups according their weight. Total fruit weight was $406,003 \mathrm{lb}$. (184,160 kg) with 
Figure 3. Local and Non-Local Fresh Food Purchases by Market Value and Percent, Sarasota County (Florida) School District, 2014-2015 (all currency in US\$)

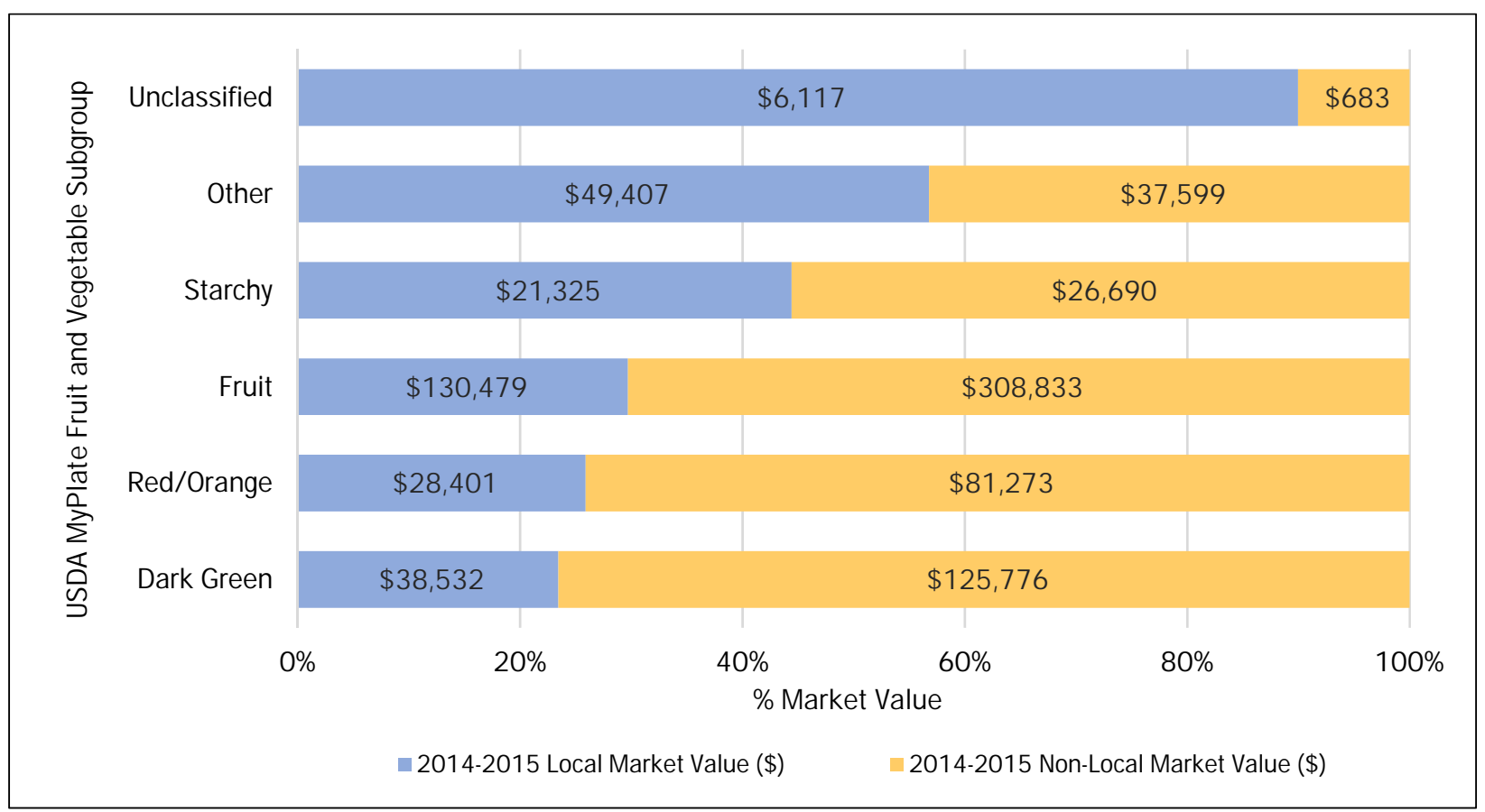

$166,376 \mathrm{lb} .(75,467 \mathrm{~kg})(41.0 \%)$ representing local fruit. Total dark green vegetables weighed 62,258 lb. $(28,240 \mathrm{~kg})$ with $10,425 \mathrm{lb} .(4,729 \mathrm{~kg})(16.7 \%)$ being from Florida (Figure 4). Red/orange vegetables had a total weight of $72,739 \mathrm{lb} .(32,994$ $\mathrm{kg})$, of which $20,629 \mathrm{lb} .(9,357 \mathrm{~kg})(28.4 \%)$ were

Figure 4. Percent of Weight for Local and Non-local Fresh Food Purchases by Subgroup, Sarasota County (Florida) School District, 2014-2015

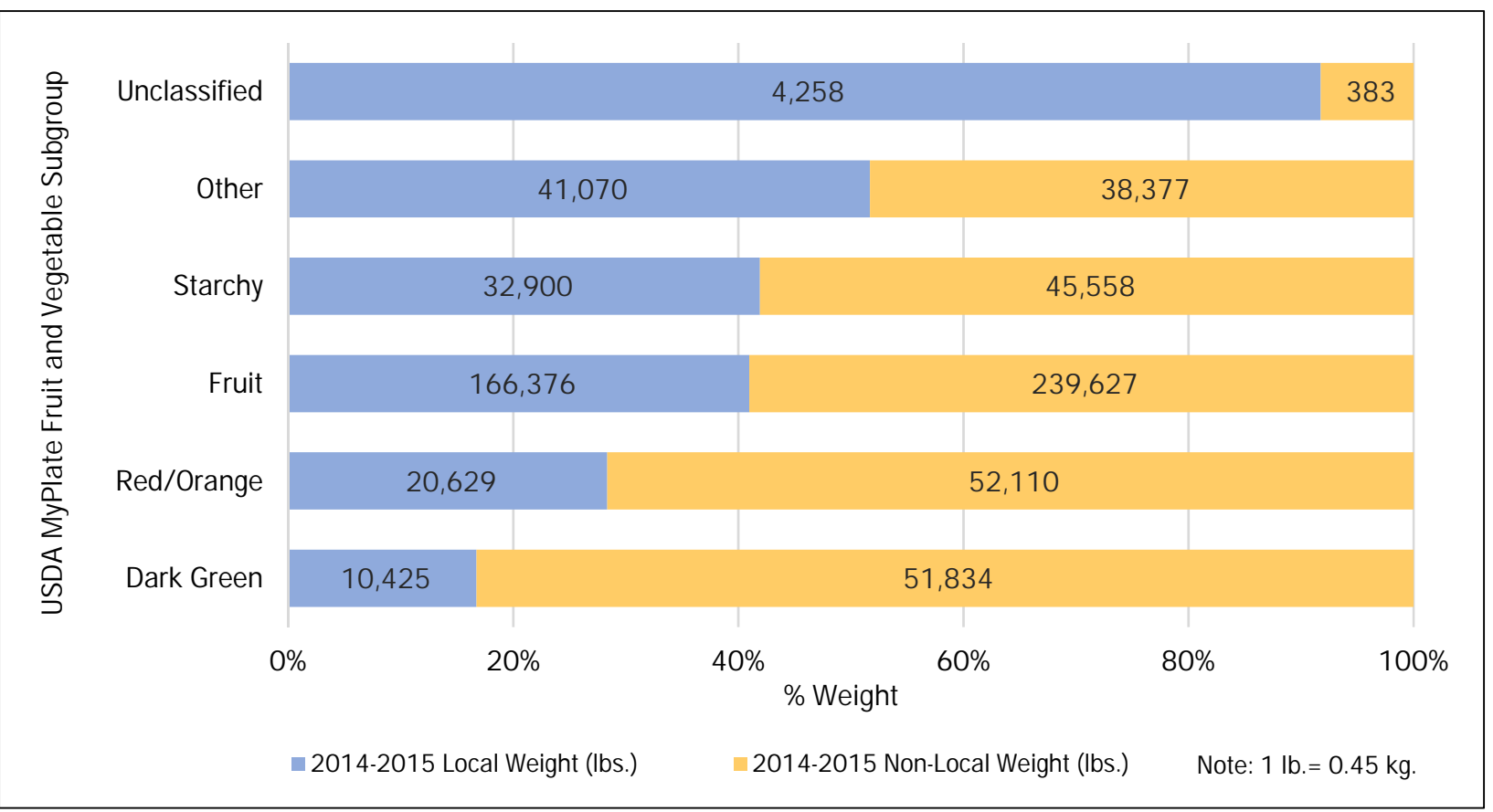


sourced locally. Vegetables categorized as other and starchy totaled 79,447 lb. (36,037 kg) and $78,458 \mathrm{lb}$. $(35,588 \mathrm{~kg})$ respectively, with other vegetables from local sources weighing 41,070 lb. $(18,629 \mathrm{~kg})(51.7 \%)$ and starchy vegetables from local sources weighing 32,900 lb. (14,923 kg) $(41.9 \%)$. Vegetables not categorized under MyPlate subgroups were "unclassified" with a total weight of 4,624 lb. (2097 kg), of which 4,258 lb. $(1931 \mathrm{~kg})(92.1 \%)$ originated from producers in Florida.

For the entire SCSD, approximately $32.1 \%$ of all food products purchased were from Florida. The five schools within the district that purchased the highest percentage of their fresh fruits and vegetables from Florida were Brookside Middle, Oak Park School, Garden Elementary, Phillippi Shores Elementary, and Laurel-Nokomis with $41.3 \%, 40.6 \%, 36.8 \%, 36.7 \%$, and $36.7 \%$, respectively. A complete list of all schools within the district ranked by the amount of Florida sourced products is in Appendix F. While it is useful to compare schools within the district regarding the percent of Florida-sourced products, not all schools are equal. Many schools have socioeconomic differences in their student population. In some schools, a high proportion of students' families are disadvantaged financially and thus these schools have a large share of the student population that are eligible to purchase reduced price lunches or are provided meals free of charge.

Separating the Title I schools from non-Title I schools allowed for a Wilcoxon Rank-Sum test. This test is appropriate when comparing two independent samples when you cannot assume that the data is normally distributed. In this instance, we are interested in the median differences of Title I schools versus non-Title I schools regarding the percent of Florida-sourced fresh fruits and vegetables as a proportion of all fresh food purchases.

The Wilcoxon Rank-Sum test for two independent samples is a non-parametric alternative to other sample tests such as the t-test, often used with the assumption of a normally distributed data, particularly in the case with small samples sizes where $\mathrm{n} \leq 30$ or the measurement level of the data is less than interval. These factors can render t-test results unreliable; therefore, the Wilcoxon RankSum test is a viable alternative of hypothesis testing. This test has non-overlapping hypotheses of the null and the alternative with the former indicating no effect and the latter suggesting some supplementary effect regarding differences in the median population.

In total, there are 38 schools with measurable data in the SCSD, of which $12\left(n_{1}\right)$ are considered Title I and $26\left(n_{2}\right)$ are non-Title I. Therefore, since our sample size in both samples is less than 30 , we cannot assume they are normally distributed; however, each of the observations in the sample data set is independent. Indeed, a histogram of the percent of local food purchases of the schools is skewed for both Title I and non-Title I schools (Figure 5).

In the analysis, the absolute value of the $\mathrm{Z}$ score was greater than the absolute of the $Z$ critical value at $\alpha=0.01$. Therefore, we can reject the null hypothesis that the median difference in locally sourced food purchases as a percent of total food purchases between Title I and nonTitle I schools in Sarasota County is equal to zero. The average Title I school in Sarasota County spent $29.6 \%$ of its fresh fruit and vegetable budget on Florida-grown products, while non-Title I schools in the district spent $34.1 \%$. Statistically significant differences in these two groups of schools likely indicate the existence of potential barriers to successful local procurement activities for Title I schools. Alternatively, these results may also reflect the effects that government support programs such as the Fresh Fruit and Vegetable Program have on local food procurement for Title I schools. In many cases, larger quantities of fresh food from these government programs are purchased by Title I schools, and the selections are much broader than the items served at lunch or breakfast, so the effect of non-local items may dilute the overall F2S local percentage. This should not necessarily be surprising given the financial resources in many Title I schools and the opportunity to participate in such programs. Nevertheless, future research should place greater focus on Title I schools to identify specific needs that will benefit these schools to procure locally sourced food products. 
Figure 5. Histogram for Locally Sourced Fresh Florida Products in 2014-2015 Academic Year for All Schools Segmented by Title I and Non-Title I Classification in Sarasota County

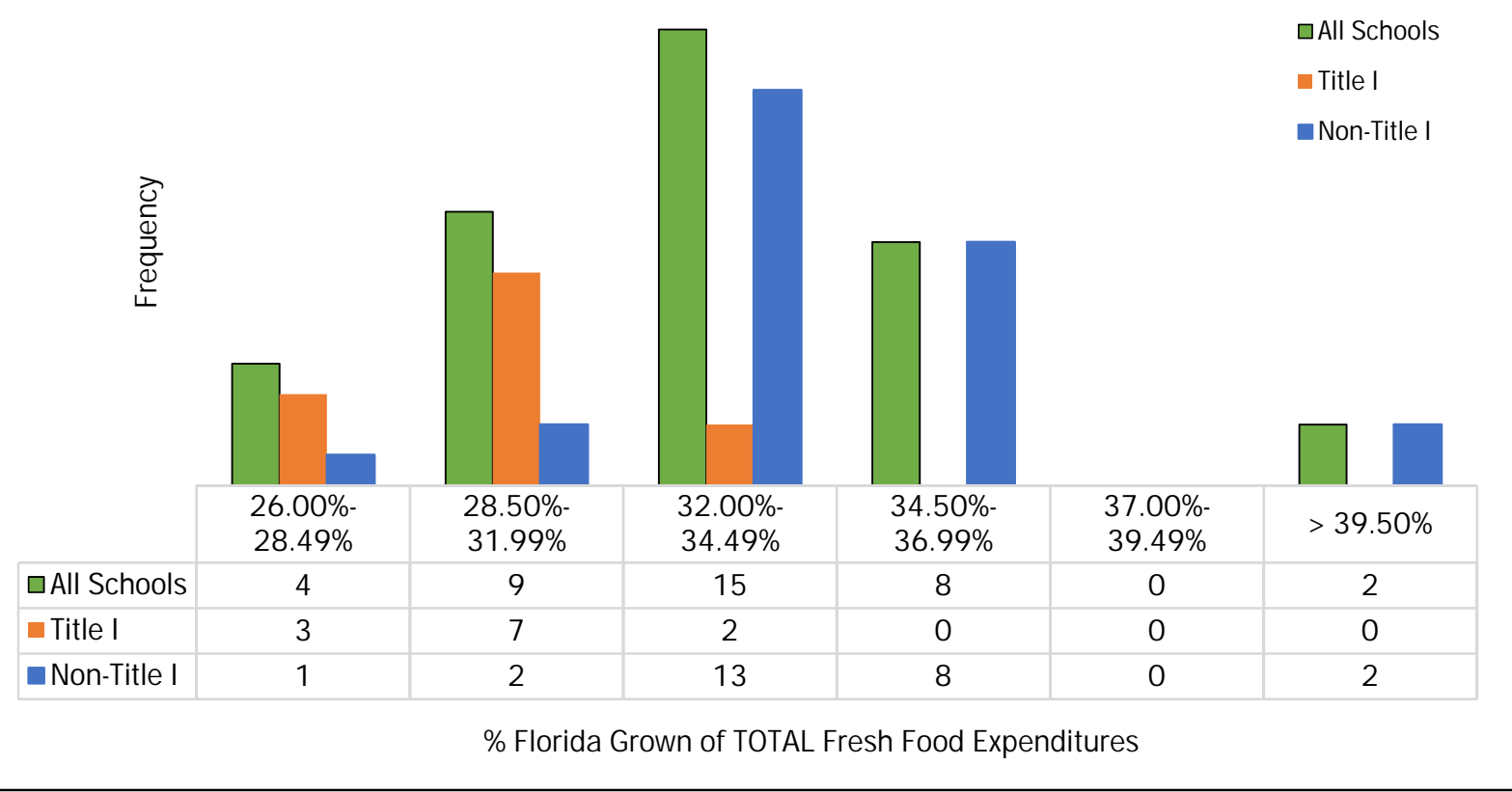

\section{Conclusions}

This article summarizes total and local food purchases, describes trends and seasonal patterns of local food purchases made by the SCSD during the 2014-2015 academic year, and identifies challenges and opportunities for expanding local procurement. Vegetables from the dark green and red/ orange categories and fruit, specifically oranges, broccoli florets, tomatoes, and cob corn, are products that show promising potential for expanding local food procurement. The seasonal nature of Florida's commercial crop production might create challenges for some producers (e.g., large producers) and opportunities for other (e.g., small producers) who otherwise might not have access to these institutional markets.

This research contributes to the literature by providing an analysis of procurement activities including type, volume, and price of select specialty crops used in an area with a high population and socioeconomic differences. While this study provides an analysis of these activities at a basic economic level, it also highlights important differences in procurement activities at schools with varying socioeconomic demographics. Title I schools in the district source fewer local products as a percent of their total food purchases compared to their nonTitle I counterparts. Ironically, it is specifically these students that F2S programs are designed to benefit the most. From the literature we found that students at Title I schools are often less knowledgable about the importance of nutrition, and in many cases food from school represents a major percentage of their caloric intake. Given these findings, we recommend that SFA provide greater support and funding to Title I schools so that they are better prepared and equipped to procure local products. Future research projects should focus on procurement strategies that assist Title I schools in maximizing their local food purchases at minimum costs.

While federal and state policies are in effect to provide funding for administrative leadership and research to expand procurement, there is little direct support at the local level. Many states, including Florida, have a statewide coordinator responsible for expanding the growth of F2S programs and helping to train educators and nutrition staff, as well as for facilitating other necessary activities. However, few school districts 
have a dedicated support staff person responsible for leading F2S procurement activities in their area. A few school districts such as Sarasota County have a dedicated F2S coordinator who acts as a point of contact for the school district administrators, producers, teachers, students, and families to strengthen the connection of local fresh food products and the community. Other school districts are not so fortunate, and while some individuals have been proactive champions-essential to the development and implementation of many F2S activities-procurement issues are likely to require additional support and assistance from trained personnel. A dedicated F2S coordinator at the district level can leverage existing relationships and facilitate the creation of new partnerships. Additionally, we recommend greater capital investment in equipment and facilities to expand access, particularly for small farmers, to this market. This includes facilities to aggregate and store product as well as equipment to minimally process products in a manner that is adequate for school foodservice and kitchen staff. The USDA offers competitive grants for implementation and planning, equipment assistance, and community facilities in addition to loans and grants authorized by the Health Hunger-Free Kids Act of 2010 and the Richard B. Russell National School Lunch Act to eligible school districts. These funds can serve multiple functions by helping to establish farm to school programs, assisting schools in feeding kids, providing healthy, local meals, teaching students about food, farming, and nutrition, and supporting local agricultural communities. Program administrators can seek additional resources from the USDA Food and Nutrition Service's Farm to School Grant Program. ${ }^{2}$

The information in this article has a wide range of implications for F2S procurement activities and policies. However, some of the most difficult obstacles to successful F2S procurement relate to distribution. Most schools rely on one or a few broadline distributors to provide them with a wide variety of products for their cafeterias. These broadline distributors often prioritize quality and volume over other differentiating characteristics such as being locally produced. School districts may attempt to coordinate delivery of local products, but in many cases, producers lack adequate transportation or the necessary time to deliver fresh food directly to schools. Schools also may lack the equipment or personnel necessary to pick up food directly from producers. Additionally, both producers and schools may be ill equipped to transport, handle, and minimally process fresh local food products. Hence schools often resort to relying on the broadline distributor to facilitate those functions, which creates a new set of problems (e.g., transparency, fewer dollars retained in the local economy, difficulty establishing longterm relationships, etc.) of which local producers have expressed frustration that stifles further F2S development. Ideally, policy would reflect the greater investment in time, money, and resources necessary to provide these stakeholders with the means to coordinate their efforts. Future research efforts should focus on coordination strategies to help farmers pool their resources, lower their costs, and provide quality products in the necessary volumes so they can directly access schools and other institutional markets.

\section{Acknowledgments}

The lead author of this paper would like to begin by acknowledging the following people who served as my committee members and for their support, guidance, and input on research materials: Dr. Jim Leary, Dr. Pierce Jones, and Dr. Lisa House. All authors would like to acknowledge the administrative and support staff in the Agricultural and Biological Engineering Department, Horticultural Sciences Department, and Food and Resource Economics Department at the University of Florida for their assistance. Their help was critical in meeting deadlines and successfully completing necessary paperwork. We would like to acknowledge the University of Florida Institute of Food and Agricultural Sciences as well as the University of Florida Farm to School and Family Nutrition Program teams for their promotion of all activities related to farm-to-school in the state of Florida. We would like to acknowledge Drs. Robert Kluson and Roy Beckford, Crystal Snodgrass,

\footnotetext{
${ }^{2}$ See the Community Food Systems page at https://www.fns.usda.gov/farmtoschool/farm-school-grant-program
} 
Vanessa Bielema, Mary Beth Henry, Alicia Whidden, and Chef David Bearl for their help with networking and contacting producers willing to provide their assistance with data collection for this research project. We would like to acknowledge the Sarasota County Food and Nutrition Services team for providing valuable school food purchase report data, which aided in identifying spending patterns by the schools in the district. The authors acknowledge James Colee from the University of Florida IFAS Statistical Counseling Unit for his assistance with statistical software and modeling advice. The authors would like to acknowledge the producers, distributors, and food processors who provided their time and expertise on all matters regarding fresh food in the state of Florida.

\section{References}

Benson, M., Russell, M., \& Kane, D. (2015). U SD A F Frm to School G rant Program FY 2013- FY 2015 summary of awards. Retrieved from https://fns-prod.azureedge.net/sites/default/files/f2s/F2S_Grant_Summary_Report.pdf

Berlin, L., Norris, K., Kolodinsky, J., \& Nelson, A. (2013). The role of social cognitive theory in farm-to-school-related activities: Implications for child nutrition. Journal of School H ealth, 83(8), 589-595. https://doi.org/10.1111/josh.12069

Bontrager Yoder, A. B. H. (2014). W isonsin farm to school programs: D ietary outoomes in elementary students (Doctoral dissertation, University of Wisconsin-Madison). Retrieved from https://search.proquest.com/docview/1551526416?pq-origsite=gscholar

Centers for Disease Control and Prevention. (2009). Nutrition standards for foods in schools: Recommended nutrition standards for foods outside of school meal programs. Retrieved from https://www.cdc.gov/healthyschools/nutrition/pdf/nutrition factsheet parents.pdf

Centers for Disease Control and Prevention. (2011). School health guidelines to promote healthy eating and physical activity. M M W R. Recommendations and Reports: M orbidity and M ortality W eekly Report, 60(RR-5), 1. Retrieved from https://www.cdc.gov/mmwr/pdf/rr/rr6005.pdf

Cohen, J. F. W., Richardson, S., Austin, S. B., Economos, C. D., \& Rimm, E. B. (2013). School lunch waste among middle school students: Nutrients consumed and costs. A merican Journal of Preventive M edicine, 44 (2), 114-121. https://doi.org/10.1016/j.amepre.2012.09.060

Colasanti, K. J. A., Matts, C., \& Hamm, M. W. (2012). Results from the 2009 Michigan farm to school survey: Participation grows from 2004. Journal of N utrition E ducation and Behavior, 44(4), 343-349. https://doi.org/10.1016/i.jneb.2011.12.003

Dehghan, M., Akhtar-Danesh, N., \& Merchant, A. T. (2005). Childhood obesity, prevalence and prevention. N utrition Journal, 4, 24. https://doi.org/10.1186/1475-2891-4-24

Drewnowski, A., \& Specter, S. E. (2004). Poverty and obesity: The role of energy density and energy costs. A merican Journal of Clinical N utrition, 79 (1), 6-16. Retrieved from http://www.ncbi.nlm.nih.gov/pubmed/14684391

Fields, S. (2004). The fat of the land: Do agricultural subsidies foster poor health? E nvironmental $\mathrm{H}$ ealth Perspectives, 112(14), A820. https://doi.org/10.1289/ehp.112-a820

Finkelstein, D. M., Hill, E. L., \& Whitaker, R. C. (2008). School food environments and policies in US public schools. Pediatrics, 122(1), e251-e259. https://doi.org/10.1542/peds.2007-2814

Gleason, P., \& Suitor, C. (2001). F ood for thought: C hildren's diets in the 1990s [Policy brief]. Retrieved from https://eric.ed.gov/?id=ED463829

Hall, E., Chai, W., \& Albrecht, J. A. (2016). Relationships between nutrition-related knowledge, self-efficacy, and behavior for fifth grade students attending Title I and non-Title I schools. A ppetite, 96, 245-253. https://doi.org/10.1016/j.appet.2015.09.033

Holcomb, R., \& Vo, A. (n.d.). Farm-to-school templates: Tools for participating producers and schools. Retrieved from http://okfarmtoschool.com/wp-content/uploads/section3-FTS-templates-2.pdf

Izumi, B. T., Alaimo, K., \& Hamm, M. W. (2010). Farm-to-school programs: Perspectives of school food service professionals. Journal of N utrition E ducation and Behavior, 42 (2), 83-91. https://doi.org/10.1016/j.jneb.2008.09.003

Izumi, B. T., Rostant, O. S., Moss, M. J., \& Hamm, M. W. (2006). Results from the 2004 Michigan farm-to-school survey. Journal of School H ealth, 76(5), 169-174. https://doi.org/10.1111/j.1746-1561.2006.00090.x 
Izumi, B. T., Wright, D. W., \& Hamm, M. W. (2010). Farm to school programs: Exploring the role of regionally-based food distributors in alternative agrifood networks. A griaulture and $\mathrm{H}$ uman V alues, 27(3), 335-350. https://doi.org/10.1007/s10460-009-9221-x

Joshi, A., Azuma, A. M., \& Feenstra, G. (2008). Do farm-to-school programs make a difference? Findings and future research needs. Journal of $\mathrm{H}$ unger \& E nvironmental N utrition, 3(2-3), 229-246. https://doi.org/10.1080/19320240802244025

Joshi, A., Henderson, T., Ratcliffe, M. M., Feenstra, G. (2014). Evaluation for transformation: A cross-sectoral evaluation framework for farm to school. National Farm to School Network. Retrieved from http://www.farmtoschool.org/resources-main/evaluation-framework

Kubik, M. Y., Lytle, L. A., Hannan, P. J., Perry, C. L., \& Story, M. (2003). The association of the school food environment with dietary behaviors of young adolescents. A merican Journal of Public H ealth, 93(7), 1168-1173. https://doi.org/10.2105/AJPH.93.7.1168

Lindsay, A. C., Sussner, K. M., Kim, J., \& Gortmaker, S. L. (2006). The role of parents in preventing childhood obesity. The F uture of C hildren, 16(1), 169-186. https:/ / doi.org/10.1353/foc.2006.0006

Morgan, K., \& Sonnino, R. (2008). The school food revolution: Public food and the challenge of sustainable development. London: Routledge.

National Farm to School Network. (n.d.-a). Home page. Retrieved July 27, 2017, from http://www.farmtoschool.org/

National Farm to School Network. (n.d.-b). About National Farm to School Network. Retrieved April 30, 2018, from http://www.farmtoschool.org/about

National Farm to School Network. (2018). State Farm to School N etworks T oolkit. Retrieved from http://www.farmtoschool.org/resources-main/state-farm-to-school-network-toolkit

National School Lunch Act of 1946, 42 U.S.C. SS 1751-1769j (2010). Retrieved from https://www.gpo.gov/fdsys/granule/USCODE-2011-title42/USCODE-2011-title42-chap13-sec1751

Roche, E., Conner, D., \& Kolodinsky, J. (2015). Increasing local procurement in farm-to-school programs: An exploratory investigation. Journal of A griaulture, F ood Systems, and Community D evelopment, 5(2), 81-90. https://doi.org/10.5304/jafscd.2015.052.019

Schoonover, H., \& Muller, M. (2006). F ood without thought: H ow U .S. farm policy contributes to obesity. Institute for Agriculture and Trade Policy. Retrieved from https://www.iatp.org/documents/food-without-thought-how-us-farm-policycontributes-obesity

Slusser, W., Prelip, M., Kinsler, J., Erausquin, J. T., Thai, C., \& Neumann, C. (2011). Challenges to parent nutrition education: A qualitative study of parents of urban children attending low-income schools. Public $\mathrm{H}$ ealth $\mathrm{N}$ utrition, 14(10), 1833-1841. https://doi.org/10.1017/S1368980011000620

Story, M. P. D., Kaphingst, K. M., \& French, S. (2006). The role of schools in obesity prevention. The Future of Children, 16(1), 109-142. https://doi.org/10.1353/foc.2006.0007

Templeton, S. B., Marlette, M. A., \& Panemangalore, M. (2005). Competitive foods increase the intake of energy and decrease the intake of certain nutrients by adolescents consuming school lunch. Journal of the A merican D ietetic A ssociation, 105(2), 215-220. https://doi.org/10.1016/i.jada.2004.11.027

U.S. Department of Agriculture [USDA]. (n.d.-a). 2012 C ensus of A griculture: County Profile: Sarasota C ounty, Florida. Retrieved from https://www.nass.usda.gov/Publications/AgCensus/2012/Online Resources/County Profiles/ Florida/cp12115.pdf

USDA. (n.d.-b). 2015 USDA Farm to School Census Data Explorer Tool. The Farm to School Census. Retrieved March 22, 2018, from https:/ / farmtoschoolcensus.fns.usda.gov/data-explorer

USDA Food \& Nutrition Service. (2016). Characteristics of Supplemental N utrition A ssistance Program H ouseholds: Fiscal Y ear 2015. Alexandria, VA. Retrieved October 24, 2018, from https://www.fns.usda.gov/ops/supplemental-nutritionassistance-program-snap-research

USDA Food \& Nutrition Service. (2017). Federal Cost of School Food Program Data. Retrieved July 28, 2017, from https://catalog.data.gov/dataset/federal-cost-of-school-food-program-data

USDA \& U.S. Department of Health and Human Services. (2010). D ietary guidelines for A mericans, 2010 (7th Ed.). Washington, D.C.: U.S. Government Printing Office Retrieved from https://health.gov/dietaryguidelines/dga2010/DietaryGuidelines2010.pdf 
U.S. Department of Health and Human Services \& USDA. (2015). 2015- 2020 dietary guidelines for A mericans (8th Ed.). Retrieved from http://health.gov/dietaryguidelines/2015/guidelines/

Vallianatos, M., Gottlieb, R., \& Haase, M. A. (2004). Farm-to-school: Strategies for urban health, combating sprawl, and establishing a community food systems approach. Journal of Planning E ducation and Research, 23(4), 414-423. https://doi.org/10.1177/0739456X04264765

Watson, J. A. (2016). C reating suceesful farm to school programs in Florida: A countywide feasibility study of direct procurement (Doctoral dissertation, University of Florida). Retrieved from http://uf.catalog.fcla.edu/permalink.jsp?20UF035102863

Watson, J. A., Treadwell, D. D., \& Bucklin, R. A. (2018). The feasibility of local food cooperatives to support farm to school proaurement in Southwest Florida. Manuscript in preparation.

Watson, J. A., Treadwell, D., Prizzia, A., \& Brew, K. (2014). A farm to school procurement calculator for specialty crop producers and school food service staff. University of Florida. Retrieved from http://edis.ifas.ufl.edu/hs1250

Winston, A. (2011). Farm to school. Maine Policy Review, 20 (1), 233-236. Retrieved from https://digitalcommons.library.umaine.edu/mpr/vol20/iss1/37/ 
Appendices

Appendix A. Food Deserts, Schools, and Agricultural Land Use for Sarasota County, Florida, 2017

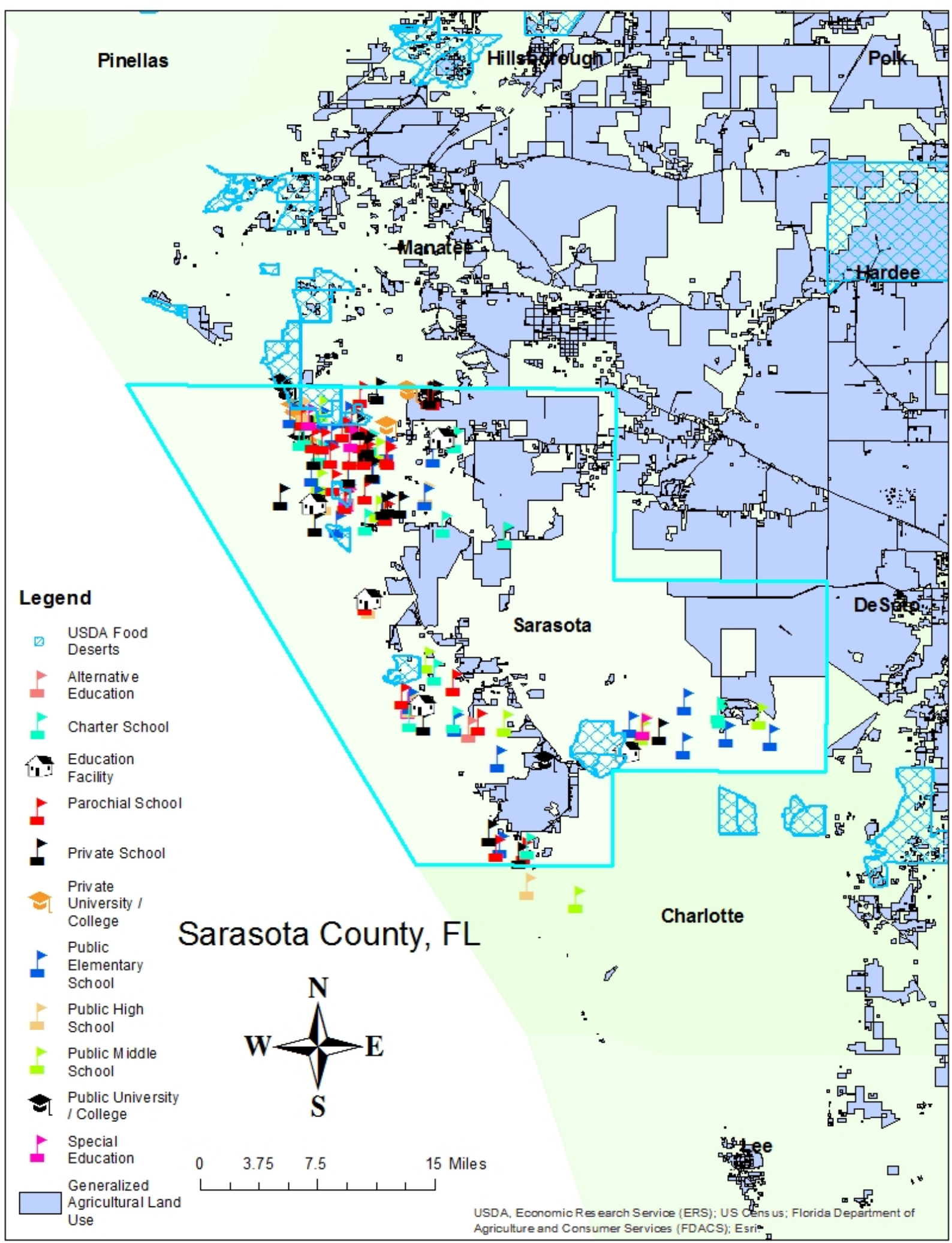


Appendix B. Schools and Number of Children Enrolled in SNAP for Sarasota County, Florida, 2017

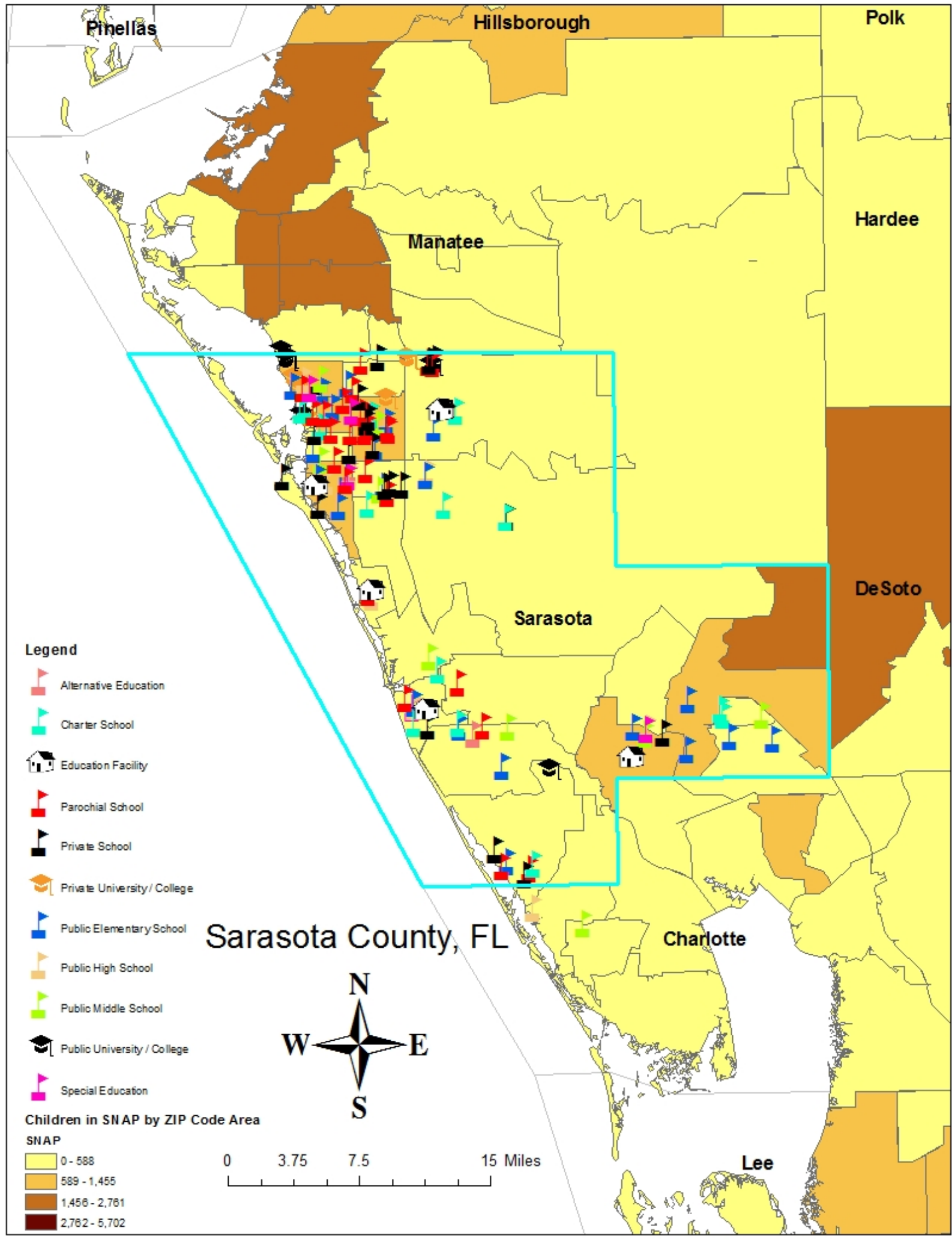


Appendix C. Equations and Variables Used for Analyzing Data

\begin{tabular}{ccl} 
Variable/ equation & Equation number & \multicolumn{1}{c}{ Description/ notes } \\
\hline$\mu_{R}=\frac{n_{1}\left(n_{1}+n_{2}+1\right)}{2}$ & 1 & Mean for the population \\
\hline$\sigma_{R}=\sqrt{\frac{n_{1} n_{2}\left(n_{1}+n_{2}+1\right)}{12}}$ & 2 & Estimate of the standard deviation \\
\hline$Z=\frac{\left(R-\mu_{R}\right)}{\sigma_{R}}$ & 3 & $\begin{array}{l}\text { Z-score normally distributed with mean of } 0 \text { and standard } \\
\text { deviation of 1 }\end{array}$ \\
\hline$n_{1}$ & Sample 1 (Title I schools) \\
\hline$n_{2}$ & Sample 2 (non- Title I schools) \\
\hline $\mathrm{N} 1$ & Sum of the ranks for sample 1 \\
\hline $\mathrm{N} 2$ & Sum of the ranks for sample 2 \\
\hline$R$ & The sum of the ranks of the smallest sample size \\
\hline
\end{tabular}


Appendix D. All Food Products Purchased by Sarasota County (Florida) School District, 2014- 2015 Academic Year

\begin{tabular}{|c|c|c|c|c|c|c|c|}
\hline \multirow[t]{2}{*}{ Product } & \multicolumn{4}{|c|}{ Annual Total } & \multicolumn{2}{|c|}{ Annual Average } & \multirow{2}{*}{$\frac{\$ \text { / Serving }}{\text { (1/ } 4 \text { cup) }}$} \\
\hline & Cost (\$) & Rank & $\begin{array}{c}\text { Weight } \\
\text { (lbs.) }\end{array}$ & Rank & $\$ / \mathrm{lb}$. & Rank & \\
\hline APPLES, SLICED & $\$ 142,982$ & 1 & 62,428 & 2 & $\$ 2.29$ & 30 & $\$ 0.20$ \\
\hline APPLES, WHOLE (RED DEL.) & $\$ 16,254$ & 15 & 13,364 & 19 & $\$ 1.22$ & 43 & $\$ 0.08$ \\
\hline BANANAS & $\$ 4,252$ & 34 & 8,080 & 20 & $\$ 0.53$ & 77 & $\$ 0.10$ \\
\hline BANANAS, JUNIOR & $\$ 37,135$ & 9 & 57,600 & 4 & $\$ 0.64$ & 70 & $\$ 0.09$ \\
\hline BASIL, FRESH & $\$ 298$ & 64 & 18 & 77 & $\$ 16.77$ & 5 & - \\
\hline BLUEBERRIES, SNACK PACK & $\$ 2,067$ & 43 & 163 & 57 & $\$ 12.72$ & 8 & $\$ 1.19$ \\
\hline BROCCOLI, FLORETS & $\$ 73,796$ & 2 & 20,858 & 12 & $\$ 3.54$ & 23 & $\$ 0.12$ \\
\hline BROCCOLI, WHOLE HEAD & $\$ 32$ & 75 & 23 & 71 & $\$ 1.38$ & 41 & $\$ 0.14$ \\
\hline CABBAGE, GREEN & $\$ 374$ & 60 & 800 & 43 & $\$ 0.47$ & 80 & $\$ 0.03$ \\
\hline CABBAGE, RED & $\$ 15$ & 78 & 30 & 69 & $\$ 0.50$ & 78 & $\$ 0.04$ \\
\hline CANTALOUPE & $\$ 1,687$ & 45 & 2,890 & 36 & $\$ 0.58$ & 74 & $\$ 0.10$ \\
\hline CARROTS, BABY & $\$ 7,971$ & 25 & 5,990 & 27 & $\$ 1.33$ & 42 & $\$ 0.10$ \\
\hline CARROTS, WHOLE & $\$ 51,798$ & 3 & 26,635 & 10 & $\$ 1.94$ & 34 & $\$ 0.19$ \\
\hline CAULIFLOWER, FLORETS & $\$ 2,415$ & 40 & 610 & 48 & $\$ 3.96$ & 19 & $\$ 0.22$ \\
\hline CAULIFLOWER, HEAD & $\$ 887$ & 49 & 320 & 53 & $\$ 2.78$ & 28 & $\$ 0.22$ \\
\hline CELERY, STICKS & $\$ 3,168$ & 36 & 970 & 40 & $\$ 3.27$ & 24 & $\$ 0.23$ \\
\hline CELERY, STICKS SNACK PACK & $\$ 624$ & 57 & 163 & 57 & $\$ 3.84$ & 21 & $\$ 0.27$ \\
\hline CELERY, WHOLE & $\$ 11,602$ & 21 & 13,880 & 17 & $\$ 0.84$ & 65 & $\$ 0.07$ \\
\hline CILANTRO, FRESH & $\$ 252$ & 68 & 43 & 68 & $\$ 5.82$ & 11 & - \\
\hline CORN, COB & $\$ 13,263$ & 18 & 16,968 & 16 & $\$ 0.78$ & 67 & $\$ 0.23$ \\
\hline CUCUMBERS & $\$ 13,393$ & 17 & 18,828 & 15 & $\$ 0.71$ & 68 & $\$ 0.06$ \\
\hline CUCUMBERS, SLICED & $\$ 2,847$ & 37 & 650 & 46 & $\$ 4.38$ & 17 & $\$ 0.35$ \\
\hline CUCUMBERS, SLICED SNACKS & $\$ 712$ & 56 & 163 & 57 & $\$ 4.38$ & 16 & $\$ 0.35$ \\
\hline DILL, FRESH & $\$ 359$ & 62 & 21 & 74 & $\$ 16.87$ & 3 & - \\
\hline EGGPLANT & $\$ 871$ & 50 & 740 & 45 & $\$ 1.18$ & 45 & $\$ 0.18$ \\
\hline EGGS, LARGE & $\$ 5,285$ & 30 & 4,523 & 32 & $\$ 1.17$ & 47 & - \\
\hline GARLIC & $\$ 133$ & 71 & 53 & 67 & $\$ 2.50$ & 29 & - \\
\hline GRAPEFRUIT & $\$ 18,316$ & 12 & 28,411 & 7 & $\$ 0.64$ & 71 & $\$ 0.10$ \\
\hline GRAPES, RED & $\$ 49,138$ & 4 & 29,736 & 6 & $\$ 1.65$ & 37 & $\$ 0.16$ \\
\hline GRAPES, WHITE & $\$ 7,227$ & 26 & 4,769 & 30 & $\$ 1.52$ & 39 & $\$ 0.14$ \\
\hline GREEN BEANS & $\$ 24,591$ & 11 & 13,780 & 18 & $\$ 1.78$ & 35 & $\$ 0.08$ \\
\hline GREENS, COLLARD & $\$ 10$ & 79 & 18 & 76 & $\$ 0.53$ & 76 & $\$ 0.09$ \\
\hline HONEYDEW & $\$ 27$ & 76 & 25 & 70 & $\$ 1.07$ & 51 & $\$ 0.22$ \\
\hline HONEYDEW, SNACK PACK & $\$ 715$ & 55 & 163 & 57 & $\$ 4.40$ & 15 & - \\
\hline KALE & $\$ 989$ & 48 & 910 & 41 & $\$ 1.09$ & 50 & $\$ 0.03$ \\
\hline LEMONS & $\$ 159$ & 70 & 106 & 64 & $\$ 1.50$ & 40 & $\$ 0.48$ \\
\hline LETTUCE, HEAD & $\$ 23$ & 77 & 23 & 72 & $\$ 1.01$ & 58 & $\$ 0.05$ \\
\hline LETTUCE, SALAD CUT & $\$ 114$ & 72 & 110 & 63 & $\$ 1.03$ & 55 & $\$ 0.05$ \\
\hline LETTUCE, SHREDDED & $\$ 2,143$ & 42 & 2,495 & 37 & $\$ 0.86$ & 62 & $\$ 0.04$ \\
\hline LETTUCE, SPRING MIX & $\$ 30,929$ & 10 & 6,450 & 25 & $\$ 4.80$ & 13 & $\$ 0.22$ \\
\hline MANGO, SLICED & $\$ 751$ & 52 & 81 & 66 & $\$ 9.24$ & 10 & $\$ 1.22$ \\
\hline MINT, FRESH & $\$ 4$ & 81 & 0 & 80 & $\$ 14.00$ & 6 & - \\
\hline ONIONS, RED & $\$ 240$ & 69 & 215 & 56 & $\$ 1.12$ & 48 & $\$ 0.12$ \\
\hline ONIONS, YELLOW & $\$ 3,499$ & 35 & 7,710 & 23 & $\$ 0.45$ & 81 & $\$ 0.05$ \\
\hline ORANGES & $\$ 48,103$ & 5 & 79,245 & 1 & $\$ 0.61$ & 73 & $\$ 0.17$ \\
\hline
\end{tabular}




\begin{tabular}{|c|c|c|c|c|c|c|c|}
\hline OREGANO, FRESH & $\$ 310$ & 63 & 18 & 75 & $\$ 16.96$ & 2 & - \\
\hline PARSLEY, FRESH & $\$ 256$ & 67 & 22 & 73 & $\$ 11.64$ & 9 & - \\
\hline PEACHES, YELLOW & $\$ 368$ & 61 & 435 & 51 & $\$ 0.84$ & 64 & $\$ 0.15$ \\
\hline PEARS, GREEN & $\$ 1,028$ & 47 & 1,163 & 39 & $\$ 0.88$ & 60 & $\$ 0.11$ \\
\hline PEARS, RED & $\$ 759$ & 51 & 803 & 42 & $\$ 0.95$ & 59 & $\$ 0.12$ \\
\hline PEPPERS, GREEN & $\$ 4,284$ & 33 & 4,160 & 34 & $\$ 1.03$ & 57 & $\$ 0.11$ \\
\hline PEPPERS, RED & $\$ 409$ & 59 & 258 & 55 & $\$ 1.58$ & 38 & $\$ 0.16$ \\
\hline PINEAPPLE & $\$ 4,887$ & 31 & 6,129 & 26 & $\$ 0.80$ & 66 & $\$ 0.11$ \\
\hline PINEAPPLE, CHUNKS SNACK & $\$ 741$ & 53 & 163 & 57 & $\$ 4.56$ & 14 & $\$ 0.71$ \\
\hline PLUMS, BLACK & $\$ 2,455$ & 39 & 2,380 & 38 & $\$ 1.03$ & 56 & $\$ 0.21$ \\
\hline PLUMS, RED & $\$ 726$ & 54 & 616 & 47 & $\$ 1.18$ & 44 & $\$ 0.24$ \\
\hline PLUOT, (MANGO TANGO) & $\$ 295$ & 65 & 280 & 54 & $\$ 1.05$ & 52 & $\$ 0.21$ \\
\hline POTATOES, FINGERLING & $\$ 5,499$ & 28 & 4,700 & 31 & $\$ 1.17$ & 46 & - \\
\hline POTATOES, IDAHO & $\$ 12,511$ & 19 & 26,740 & 9 & $\$ 0.47$ & 79 & $\$ 0.05$ \\
\hline POTATOES, RED & $\$ 16,742$ & 13 & 30,050 & 5 & $\$ 0.56$ & 75 & $\$ 0.06$ \\
\hline POTATOES, SWEET & $\$ 5,463$ & 29 & 7,888 & 22 & $\$ 0.69$ & 69 & $\$ 0.10$ \\
\hline PUMELO, SNACK PACK & $\$ 1,780$ & 44 & 346 & 52 & $\$ 5.15$ & 12 & - \\
\hline PUMPKIN, CHUNKS & $\$ 2,326$ & 41 & 600 & 49 & $\$ 3.88$ & 20 & - \\
\hline RADISH, RED & $\$ 103$ & 73 & 99 & 65 & $\$ 1.04$ & 54 & $\$ 0.08$ \\
\hline ROMAINE, CHOPPED & $\$ 44,534$ & 7 & 25,548 & 11 & $\$ 1.74$ & 36 & - \\
\hline ROMAINE, WHOLE & $\$ 4,479$ & 32 & 5,131 & 29 & $\$ 0.87$ & 61 & $\$ 0.03$ \\
\hline ROSEM ARY, FRESH & $\$ 4$ & 81 & 0 & 80 & $\$ 14.00$ & 6 & - \\
\hline SAGE, FRESH & $\$ 5$ & 80 & 0 & 80 & $\$ 18.00$ & 1 & - \\
\hline SPINACH & $\$ 9,285$ & 22 & 3,299 & 35 & $\$ 2.81$ & 27 & $\$ 0.09$ \\
\hline SQUASH, BUTTERNUT & $\$ 1,620$ & 46 & 510 & 50 & $\$ 3.18$ & 26 & $\$ 0.42$ \\
\hline SQUASH, YELLOW & $\$ 5,960$ & 27 & 5,445 & 28 & $\$ 1.09$ & 49 & $\$ 0.15$ \\
\hline SQUASH, ZUCCHINI & $\$ 8,400$ & 24 & 8,043 & 21 & $\$ 1.04$ & 53 & $\$ 0.09$ \\
\hline SQUASH, Z\&Y SNACK & $\$ 611$ & 58 & 163 & 57 & $\$ 3.76$ & 22 & - \\
\hline STRAWBERRIES & $\$ 45,454$ & 6 & 19,989 & 13 & $\$ 2.27$ & 31 & $\$ 0.29$ \\
\hline TANGERINES & $\$ 37,148$ & 8 & 57,915 & 3 & $\$ 0.64$ & 72 & $\$ 0.08$ \\
\hline THYME, FRESH & $\$ 286$ & 66 & 17 & 78 & $\$ 16.79$ & 4 & - \\
\hline TOMATOES & $\$ 16,389$ & 14 & 19,199 & 14 & $\$ 0.85$ & 63 & $\$ 0.11$ \\
\hline TOMATOES, CHERRY & $\$ 8,856$ & 23 & 4,172 & 33 & $\$ 2.12$ & 32 & $\$ 0.18$ \\
\hline TOMATOES, GRAPE & $\$ 14,843$ & 16 & 7,486 & 24 & $\$ 1.98$ & 33 & $\$ 0.16$ \\
\hline WATERMELON & $\$ 12,325$ & 20 & 27,946 & 8 & $\$ 0.44$ & 82 & $\$ 0.00$ \\
\hline WATERMELON, SNACK PACK & $\$ 2,535$ & 38 & 780 & 44 & $\$ 3.25$ & 25 & - \\
\hline TOTAL FRESH FOOD & \multirow{2}{*}{\multicolumn{2}{|c|}{$\begin{array}{l}\$ 855,102 \\
\$ 849,817\end{array}$}} & \multirow{2}{*}{\multicolumn{5}{|c|}{$\begin{array}{l}703,555 \\
699,032\end{array}$}} \\
\hline TOTAL FRESH PRODUCE & & & & & & & \\
\hline
\end{tabular}


Appendix E. Local Food Products Purchased by Sarasota County (Florida) School District, 2014-2015 Academic Year

\begin{tabular}{|c|c|c|c|c|c|c|c|}
\hline \multirow[t]{2}{*}{ Product } & \multicolumn{4}{|c|}{ Annual Total } & \multicolumn{2}{|c|}{ Annual Average } & \multirow{2}{*}{ \$/ Serving } \\
\hline & $\operatorname{Cost}(\$)$ & Rank & $\begin{array}{l}\text { Weight } \\
\text { (lbs.) }\end{array}$ & Rank & $\$ / \mathrm{lb}$. & Rank & \\
\hline BASIL, FRESH & $\$ 293$ & 30 & 17 & 34 & $\$ 17.00$ & 1 & - \\
\hline BROCCOLI, FLORETS & $\$ 5,477$ & 14 & 1,563 & 20 & $\$ 3.50$ & 10 & $\$ 0.12$ \\
\hline BROCCOLI, WHOLE HEAD & $\$ 420$ & 25 & 603 & 23 & $\$ 0.70$ & 29 & $\$ 0.07$ \\
\hline CABBAGE, GREEN & $\$ 374$ & 26 & 800 & 21 & $\$ 0.47$ & 35 & $\$ 0.03$ \\
\hline CABBAGE, RED & $\$ 15$ & 36 & 30 & 30 & $\$ 0.50$ & 34 & $\$ 0.04$ \\
\hline CAULIFLOWER, FLORETS & $\$ 2,392$ & 20 & 604 & 22 & $\$ 3.96$ & 8 & $\$ 0.22$ \\
\hline CAULIFLOWER, HEAD & $\$ 882$ & 22 & 314 & 24 & $\$ 2.81$ & 11 & $\$ 0.22$ \\
\hline CELERY, STICKS & $\$ 624$ & 24 & 163 & 27 & $\$ 3.84$ & 9 & $\$ 0.27$ \\
\hline CELERY, WHOLE & $\$ 4,799$ & 18 & 6,770 & 10 & $\$ 0.71$ & 28 & $\$ 0.06$ \\
\hline CUCUMBERS & $\$ 7,076$ & 10 & 9,672 & 9 & $\$ 0.73$ & 27 & $\$ 0.07$ \\
\hline CUCUMBERS, SLICED & $\$ 712$ & 23 & 163 & 27 & $\$ 4.38$ & 7 & $\$ 0.35$ \\
\hline DILL, FRESH & $\$ 355$ & 28 & 21 & 31 & $\$ 16.90$ & 4 & - \\
\hline EGGS, LARGE & $\$ 4,882$ & 16 & 4,185 & 16 & $\$ 1.17$ & 20 & - \\
\hline GRAPEFRUIT & $\$ 11,855$ & 7 & 20,194 & 4 & $\$ 0.59$ & 31 & $\$ 0.09$ \\
\hline GREEN BEANS & $\$ 19,968$ & 5 & 11,100 & 8 & $\$ 1.80$ & 15 & $\$ 0.08$ \\
\hline KALE & $\$ 230$ & 33 & 193 & 26 & $\$ 1.19$ & 18 & $\$ 0.03$ \\
\hline LETTUCE, HEAD & $\$ 16$ & 35 & 13 & 36 & $\$ 1.28$ & 17 & $\$ 0.06$ \\
\hline LETTUCE, SPRING MIX & $\$ 30,851$ & 4 & 6,392 & 11 & $\$ 4.83$ & 6 & $\$ 0.22$ \\
\hline ORANGES & $\$ 33,978$ & 2 & 59,940 & 1 & $\$ 0.57$ & 32 & $\$ 0.16$ \\
\hline OREGANO, FRESH & $\$ 306$ & 29 & 18 & 33 & $\$ 17.00$ & 1 & - \\
\hline PARSLEY, FRESH & $\$ 252$ & 32 & 21 & 31 & $\$ 12.00$ & 5 & - \\
\hline PEPPERS, GREEN & $\$ 2,407$ & 19 & 2,316 & 18 & $\$ 1.04$ & 23 & $\$ 0.11$ \\
\hline PEPPERS, RED & $\$ 361$ & 27 & 228 & 25 & $\$ 1.58$ & 16 & $\$ 0.16$ \\
\hline POTATOES, FINGERLING & $\$ 5,499$ & 13 & 4,700 & 14 & $\$ 1.17$ & 19 & $\$ 0.12$ \\
\hline POTATOES, RED & $\$ 15,826$ & 6 & 28,200 & 3 & $\$ 0.56$ & 33 & $\$ 0.06$ \\
\hline RADISH, RED & $\$ 75$ & 34 & 80 & 29 & $\$ 0.94$ & 24 & $\$ 0.07$ \\
\hline ROMAINE, WHOLE & $\$ 1,302$ & 21 & 1,653 & 19 & $\$ 0.79$ & 26 & $\$ 0.03$ \\
\hline SQUASH, YELLOW & $\$ 4,867$ & 17 & 4,285 & 15 & $\$ 1.14$ & 21 & $\$ 0.16$ \\
\hline SQUASH, ZUCCHINI & $\$ 5,201$ & 15 & 4,763 & 13 & $\$ 1.09$ & 22 & $\$ 0.09$ \\
\hline STRAWBERRIES & $\$ 44,896$ & 1 & 19,809 & 5 & $\$ 2.27$ & 12 & $\$ 0.29$ \\
\hline TANGERINES & $\$ 33,903$ & 3 & 52,965 & 2 & $\$ 0.64$ & 30 & $\$ 0.08$ \\
\hline THYME, FRESH & $\$ 281$ & 31 & 17 & 35 & $\$ 17.00$ & 1 & - \\
\hline TOMATOES & $\$ 11,119$ & 9 & 12,638 & 7 & $\$ 0.88$ & 25 & $\$ 0.12$ \\
\hline TOMATOES, CHERRY & $\$ 5,745$ & 12 & 2,579 & 17 & $\$ 2.23$ & 13 & $\$ 0.18$ \\
\hline TOMATOES, GRAPE & $\$ 11,176$ & 8 & 5,184 & 12 & $\$ 2.16$ & 14 & $\$ 0.18$ \\
\hline WATERMELON & $\$ 5,848$ & 11 & 13,468 & 6 & $\$ 0.43$ & 36 & $\$ 0.00$ \\
\hline TOTAL FRESH FOOD & $\$ 274,261$ & & 275,657 & & & & \\
\hline TOTAL FRESH PRODUCE & $\$ 269,379$ & & 271,472 & & & & \\
\hline
\end{tabular}


Appendix F. Total and Local Fresh Fruit And Vegetable Purchases of Sarasota County (Florida) School District by School, 2014-2015 Academic Year

\begin{tabular}{|c|c|c|c|c|c|}
\hline \multirow[t]{2}{*}{ School } & \multicolumn{4}{|c|}{ Totals } & \multirow{2}{*}{$\begin{array}{c}\text { Title I Schoo } \\
\text { Yes/ No }\end{array}$} \\
\hline & ALL & Florida & $\begin{array}{l}\text { \% Sourced from } \\
\text { Florida }\end{array}$ & Rank & \\
\hline Alta Vista Elementary-Sarasota & $\$ 59,053$ & $\$ 17,550$ & $29.7 \%$ & 32 & Yes \\
\hline Ashton Elementary & $\$ 16,167$ & $\$ 5,398$ & $33.4 \%$ & 16 & No \\
\hline Atwater Elementary & $\$ 25,343$ & $\$ 7,417$ & $29.3 \%$ & 33 & Yes \\
\hline Bay Haven School & $\$ 14,857$ & $\$ 5,090$ & $34.3 \%$ & 11 & No \\
\hline Booker High & $\$ 19,071$ & $\$ 6,422$ & $33.7 \%$ & 13 & No \\
\hline Booker Middle & $\$ 22,906$ & $\$ 7,375$ & $32.2 \%$ & 24 & Yes \\
\hline Brentwood Elementary & $\$ 21,230$ & $\$ 7,098$ & $33.4 \%$ & 15 & Yes \\
\hline Brookside Middle & $\$ 12,834$ & $\$ 5,299$ & $41.3 \%$ & 1 & No \\
\hline Cranberry Elementary & $\$ 23,926$ & $\$ 6,898$ & $28.8 \%$ & 35 & Yes \\
\hline Emma E Booker Elementary & $\$ 46,266$ & $\$ 12,410$ & $26.8 \%$ & 37 & Yes \\
\hline Englewood Elementary & $\$ 13,657$ & $\$ 4,448$ & $32.6 \%$ & 21 & No \\
\hline Fruitville Elementary & $\$ 14,782$ & $\$ 5,377$ & $36.4 \%$ & 6 & No \\
\hline Garden Elementary & $\$ 19,025$ & $\$ 6,992$ & $36.8 \%$ & 3 & No \\
\hline Glenallen Elementary & $\$ 31,760$ & $\$ 8,416$ & $26.5 \%$ & 38 & Yes \\
\hline Gocio Elementary & $\$ 19,353$ & $\$ 5,790$ & $29.9 \%$ & 31 & Yes \\
\hline Gulf Gate Elementary & $\$ 17,546$ & $\$ 5,642$ & $32.2 \%$ & 25 & No \\
\hline Heron Creek Middle & $\$ 21,028$ & $\$ 7,486$ & $35.6 \%$ & 8 & No \\
\hline Lakeview Elementary & $\$ 25,789$ & $\$ 8,422$ & $32.7 \%$ & 20 & No \\
\hline Lamarque Elementary & $\$ 37,616$ & $\$ 11,527$ & $30.6 \%$ & 29 & Yes \\
\hline Laurel-Nokomis & $\$ 27,647$ & $\$ 10,148$ & $36.7 \%$ & 5 & No \\
\hline Mclntosh Middle & $\$ 15,147$ & $\$ 5,281$ & $34.9 \%$ & 10 & No \\
\hline North Port High & $\$ 33,563$ & $\$ 10,871$ & $32.4 \%$ & 22 & No \\
\hline Oak Park School & $\$ 18,158$ & $\$ 7,372$ & $40.6 \%$ & 2 & No \\
\hline Phillippi Shores Elementary & $\$ 18,162$ & $\$ 6,669$ & $36.7 \%$ & 4 & No \\
\hline Pine View School & $\$ 17,700$ & $\$ 4,647$ & $26.3 \%$ & 39 & No \\
\hline Riverview High & $\$ 26,112$ & $\$ 7,631$ & $29.2 \%$ & 34 & No \\
\hline Sarasota High & $\$ 28,222$ & $\$ 10,035$ & $35.6 \%$ & 9 & No \\
\hline Sarasota Middle & $\$ 18,385$ & $\$ 6,176$ & $33.6 \%$ & 14 & No \\
\hline Southside Elementary & $\$ 11,451$ & $\$ 4,082$ & $35.7 \%$ & 7 & No \\
\hline Tatum Ridge Elementary & $\$ 25,133$ & $\$ 8,475$ & $33.7 \%$ & 12 & No \\
\hline Taylor Ranch Elementary & $\$ 17,424$ & $\$ 5,712$ & $32.8 \%$ & 19 & No \\
\hline Toledo Blade Elementary & $\$ 21,238$ & $\$ 6,435$ & $30.3 \%$ & 30 & Yes \\
\hline Tuttle Elementary & $\$ 20,408$ & $\$ 6,337$ & $31.0 \%$ & 28 & Yes \\
\hline Venice Elementary & $\$ 13,478$ & $\$ 4,202$ & $31.2 \%$ & 27 & No \\
\hline Venice High & $\$ 22,549$ & $\$ 7,514$ & $33.3 \%$ & 17 & No \\
\hline Venice Middle & $\$ 11,573$ & $\$ 3,728$ & $32.2 \%$ & 23 & No \\
\hline Wilkinson Elementary & $\$ 18,187$ & $\$ 4,894$ & $26.9 \%$ & 36 & Yes \\
\hline Woodland Middle & $\$ 28,363$ & $\$ 9,399$ & $33.1 \%$ & 18 & No \\
\hline TOTAL & $\$ 855,103$ & $\$ 274,664$ & & & \\
\hline
\end{tabular}

